\title{
WHAT IS THE RELATIONSHIP BETWEEN FDI AND ECONOMIC GROWTH? EVIDENCE FROM EU15 COUNTRIES
}

\author{
Vlatka Bilas \\ PhD, Full Professor, University of Zagreb, Faculty of Economics and Business, \\ Department of International Economics, Trg J. F. Kenedyja 6, 10000 Zagreb, Croatia; \\ e-mail: bilas.vlatka@gmail.com
}

\begin{abstract}
The aim of the paper is to examine the relationship between foreign direct investment (FDI) and economic growth in EU15 countries over the period 2002-2018. EU15 makes a group of countries which entered the EU prior to the biggest enlargement in 2004, namely latest in 1995 (Austria, Belgium, Denmark, Finland, France, Germany, Greece, Ireland, Italy, Luxembourg, Netherlands, Portugal, Spain, Sweden and United Kingdom). Paper findings contribute to the existing literature on the impact of FDI on economic growth. It employs different unit root tests, panel cointegration test (ARDL model) and Granger causality. Estimated panel ARDL model found some evidence that there are long-run equilibrium between LogGDP, LogFDI and LogFDIP series. The rate of adjustment back to equilibrium is between $4.43 \%$ and $5.95 \%$. The long-run coefficients are all positive, but not all of them are statistically significant. In case of LogFDIP series long-run coefficients are statistically significant, varying between 0.1226 and 0.4398 . These coefficients indicate that $1 \%$ increase in LogFDIP (logarithm of FDI to GDP) increases LogGDP between $0.1226 \%$ and $0.4398 \%$. Results of Dumitrescu-Hurlin panel causality test indicated that there is only unidirectional causal relationship from GDP growth rate to FDI growth rate, and from GDP growth rate to LogFDIP. Conclusively, there is only a weak evidence that FDI had statistically significant impact on the GDP in EU15 countries.
\end{abstract}

Key words: unit root tests, cointegration test, Granger causality, EU15

\section{INTRODUCTION}

Although projection of the global FDI flows were that FDI will increase by about 5\% in 2018 (UNCTAD, 2018), global FDI decreased in 2018 by 13\% (UNCTAD (2019). Analysing the FDI flows over the period 1990-2018, it can be concluded that in 1990 more than $60 \%$ of FDI inflow in 
developed countries went to Europe. In the observed period, the share of Europe was highest in 2005 when it exceeded $80 \%$ and after 2005 share of Europe started to decline to $31 \%$ in 2018.

In order to stimulate economic growth countries liberalise trade, the movement of capital, and even the labor. Related to FDI, they liberalise the movement of capital expecting positive effects on their economy from FDI inflows. The trends of proliferation and deepening regional economic integrations led to the liberalization of the movement of capital within and beyond regional economic integrations (Bilas, 2007). Developing countries try to attract more FDI with their incentives due to the expectation of a positive impact on the host economy (Kersan Skabic, 2013).

Many authors examined the effects of FDI on the host economy (Carbonell and Werner, 2018). There is a spread belief that FDI promotes economic development (Alfaro et al., 2010; Hunady and Orviska, 2014), especially in developing countries (Sokang, 2018). De Mello (1997) found that impact of FDI on output growth in the host economy depends on the scope of efficiency spillovers to domestic firms. Borensztein, De Gregorio and Lee (1998) examined the effect of FDI on economic growth for the period 1970-1989 on the sample of 69 developing countries and concluded that the effect of FDI on economic growth is dependent on the level of human capital available in the host economy. Gürsoy, Sekreter and Kalyoncu (2013) found biased results on the relationship between GDP and economic growth in the observed period 1997-2010.

lamsiraroj and Doucouliagos (2015) applied meta-regression analysis to 946 estimates from 140 empirical studies. They found robust positive correlation between economic growth and FDI, significantly larger for single country case studies than with cross-country analysis. Similarly, Ozturk (2007) analysed literature on the relationship between FDI and economic growth and found that consensus has been reached that FDI tends to have significant effect on economic growth through multiple channels. On the other hand, Alfaro et al. (2010) claim that empirical literature finds weak support for an exogenous positive effect of FDI on economic growth.

Jirasavetakul and Rahman (2018) found FDI has played a strong role in the export-led growth of new European Union member countries. De Mello (1999) found on the sample of OECD and nonOECD countries over the period 1970-1990 that extent to which FDI fosters economic growth depends upon the level of complementarity and substitution of FDI and domestic investment. Ekananda and Parlinggoman (2017) found positive role of FDI and domestic investment on economic growth on the sample of 50 countries over the period 1992-2014.

Kurecic and Kozina (2017) examined the correlation between GDP and FDI in EU15 countries over the period 1980-2014 and found most of the EU15 member countries show a significant correlation. Tang (2015) examined the FDI effects on economic growth of the European Union member countries over the period 1987-2012 and concluded that EU countries can maintain sustainable higher growth by attracting more FDI.

Angelopoulou and Liargovas (2014) examined the relationship between FDI and economic growth for three group of countries, EU members, EMU members and transition countries, over the period 1989-2008 and found no robust causality relationship between FDI and economic growth. 
Hlavacek and Bal-Domanska (2016) examined the impact of FDI on economic growth on the sample of Central and Eastern European countries (Czech Republic, Estonia, Hungary, Latvia, Lithuania, Poland, Slovakia and Slovenia) over the period 2000-2012 and found statistically significant relation between FDI and GDP, as well as growth of the FDI positively impacts growth of the GDP. Carstensen and Toubal (2004) examined the determinants of FDI into Central and Eastern European countries in the period 1993-1999 and identified the factors which encourage inflow of the FDI: market potential, low relative unit labor costs and skilled labor force. On the other side, Dhakal, Mixon and Upadhyaya (2007) on the same sample of countries for the period 1995-2004 found following determinants of FDI: real exchange rate, openness of the economy and deregulation. Furthermore, Jude and Pop Silaghi (2016) examined the impact of FDI on aggregate employment in Central and Eastern European countries for the observed period 1995-2012 and found a negative short run effect on employment which becomes positive in the long run.

Schmitt and Alexiou (2016) examined the FDI led growth hypothesis in Ireland over the period 1976-2011, using annual data. They found, among others, significant relationship between FDI and GDP, as well as unidirectional Granger causality from GDP to FDI. Similarly, Sârbu and Carp (2015) found that FDI has a positive effect on the economic growth in Romanian over the period 20002013.

Kikerkova et al. (2018) examined the impact of the FDI inflow on the economic growth of Macedonia over the period 2003-2015 and found positive bidirectional relationship, higher GDP can lead to higher FDI inflows, as well as the increase in FDI can cause positive reaction to the economic growth.

Mahmoodi and Mahmoodi (2016) examined the causal relationship between FDI, exports and economic growth in two panels of developing countries - eight European developing countries over the period 1992-2013 and eight Asian developing countries over the period 1986-2013. They found in the European developing panel bidirectional causality between GDP and FDI, as well as unidirectional causality from GDP and FDI to exports and for Asian developing panel bidirectional causality between exports and economic growth in short run. However, they found in the long run causality from export and FDI to economic growth, and causality from economic growth and export to FDI for both of the panels.

Chowdhury and Mavrotas (2006) examined the causal relationship between FDI and economic growth on the sample of Chile, Malaysia and Thailand over the period 1969-2000 and found GDP causes FDI in the case of Chile (unidirectional causality), while for both Malaysia and Thailand, there is a strong evidence of a bidirectional causality between the two variables. Suliman et al. (2018) found bidirectional relationship between FDI and economic growth - FDI boosts growth and the growth rate stimulates positively FDI inwards, for the Economic and Social Commission for Western Asia countries over the period 1980-2011. Iqbal et al. (2013) examined the relationship between FDI and GDP in Pakistan over the period 1983-2012 and found positive relationship between FDI and GDP. Similarly, Rahaman and Chakraborty (2015) examined the causal relationship between FDI and GDP in Bangladesh over the period 1987-2011 and found long-run equilibrium relationship and Granger unidirectional causality from FDI to GDP. 
Empirical evidence of the relationship between FDI and economic growth has been mixed. Therefore, the aim of the paper is to examine the relationship between FDI and GDP in EU15 countries. EU15 makes a group of countries which entered the EU prior to the biggest enlargement in 2004, namely latest in 1995 (Austria, Belgium, Denmark, Finland, France, Germany, Greece, Ireland, Italy, Luxembourg, Netherlands, Portugal, Spain, Sweden and United Kingdom). The hypothesis of the paper is that FDI positively impacts GDP in EU15 countries.

Paper is divided into four parts. After the introduction, second part refers to methodology and data. Third part of the paper presents empirical analysis, results and discussion. Conclusion is given in the fourth part of the paper.

\section{METHODOLOGY AND DATA}

Paper employed different unit root tests, panel cointegration test (ARDL model) and Granger causality test using EViews v. 10 and Stata v. 15 in order to examine relationship between FDI and economic growth in the EU15 countries (Austria, Belgium, Denmark, Finland, France, Germany, Greece, Ireland, Italy, Luxembourg, Netherlands, Portugal, Spain, Sweden and United Kingdom) over the period 2002-2018. This is a balanced panel with 17 observations for each series and each country. EU15 countries make a group of countries which entered the EU prior to the biggest enlargement in 2004, namely latest in 1995 (Austria, Finland and Sweden).

Annual data for FDI and GDP were retrieved from the World Bank, World Development Indicators. Variables' description is presented in Table 1.

Table 1. Variables definition

\begin{tabular}{ll}
\hline Variable & Description \\
\hline GDP & $\begin{array}{l}\text { GDP, PPP (constant 2011 international \$), PPP GDP is gross domestic product converted } \\
\text { to international dollars using purchasing power parity rates. }\end{array}$ \\
FDI & Foreign direct investment, net inflows (BoP, current US\$) \\
FDIP & Foreign direct investment, net inflows (\% of GDP) \\
rGDP & GDP growth rate (\%) \\
rFDI & FDI growth rate (\%) \\
rFDIP & FDIP growth rate (\%) \\
LogGDP & Natural logarithm of GDP series \\
LogFDI & Natural logarithm of FDI series \\
LogFDIP & Natural logarithm of FDIP series \\
$\Delta$ LogGDP & The first difference of LogGDP series \\
$\Delta$ LogFDI & The first difference of LogFDI series \\
$\Delta$ LogFDIP & The first difference of LogFDIP series \\
\hline
\end{tabular}


Table 2. Descriptive statistics for EU15 members

\begin{tabular}{cccccc}
\hline Variable & Obs & Mean & Std. Dev. & Min & Max \\
\hline gdp4 & 255 & $1.01 \mathrm{e}+12$ & $1.03 \mathrm{e}+12$ & $3.79 \mathrm{e}+10$ & $3.81 \mathrm{e}+12$ \\
fdi & 255 & $4.18 \mathrm{e}+10$ & $7.96 \mathrm{e}+10$ & $-2.39 \mathrm{e}+11$ & $7.34 \mathrm{e}+11$ \\
fdip & 255 & 6.992461 & 14.45328 & -58.32288 & 86.61077 \\
rgdp4 & 255 & 1.521327 & 2.996384 & -9.13254 & 25.16233 \\
rfdi & 253 & 274.9144 & 3530.726 & -843.0771 & 55862.27 \\
rfdip & 253 & 255.694 & 3430.596 & -760.4657 & 54347.48 \\
loggdp4 & 255 & 27.04025 & 1.162207 & 24.35926 & 28.96899 \\
logfdi & 255 & 19.4214 & 13.61418 & -26.20086 & 27.32179 \\
logfdip & 255 & 1.327866 & 1.400505 & -4.082995 & 4.472904 \\
dloggdp4 & 255 & .0146727 & .0291417 & -.095768 & .2244415 \\
dlogfdi & 253 & -.7039818 & 16.65308 & -51.49107 & 48.55619 \\
dlogfdip & 253 & -.0815229 & 1.480817 & -8.426331 & 6.703549 \\
\hline
\end{tabular}

Original series: gdp4, fdi, fdip. Growth rates: rgdp4, rfdi, rfdip. Logarithm transformation: loggdp4, logfdi, logfdip. The first difference: dloggdp4 dlogfdi dlogfdip

Source: Author's calculation

\section{EMPIRICAL ANALYSIS, RESULTS AND DISCUSSION}

\section{1 Unit root tests}

Levin-Lin-Chu (2002) and Breitung $(2000,2002)$ tests are using $t$ - statistic to test the null hypothesis of common unit root. Im-Pesaran-Shin (2003) with W-statistic, ADF (Dickey and Fuller, 1979, 1981) Fisher and PP Fisher with Chi-square statistics are testing the null hypothesis of individual unit root against an alternative hypothesis of some cross-sections without unit root. Finally, the null hypothesis of stationarity was tested using Hadri (2000) Z-statistic and heteroscedastic consistent Z-statistic. The results are presented in Table 3. 


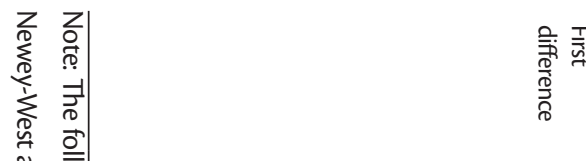

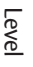

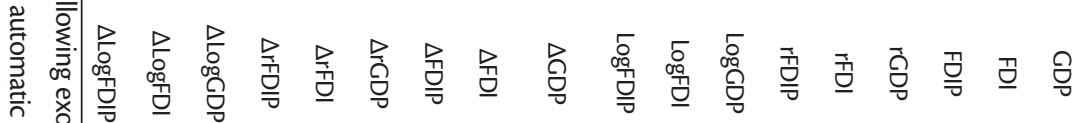

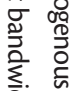

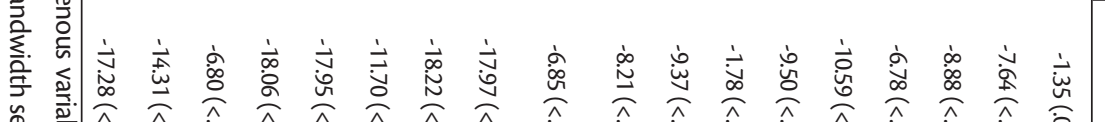

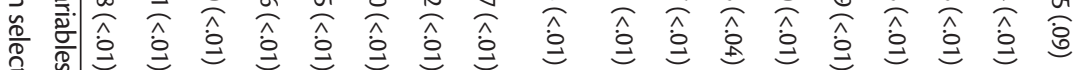
它.

气 $\frac{0}{2}$

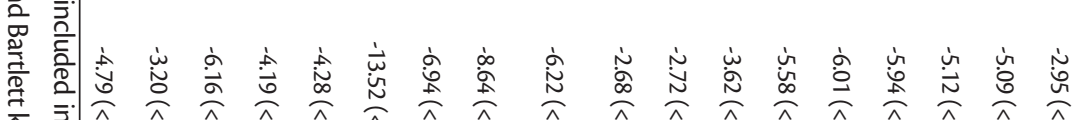

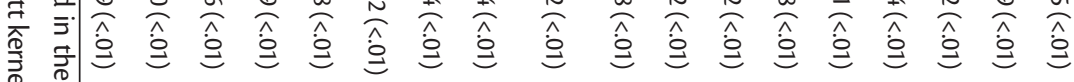

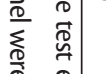



空

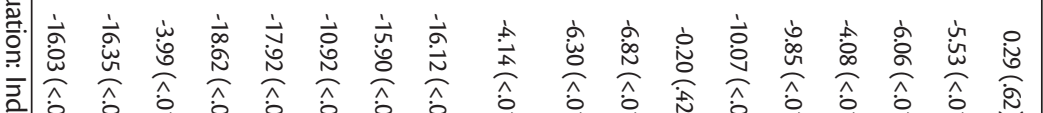

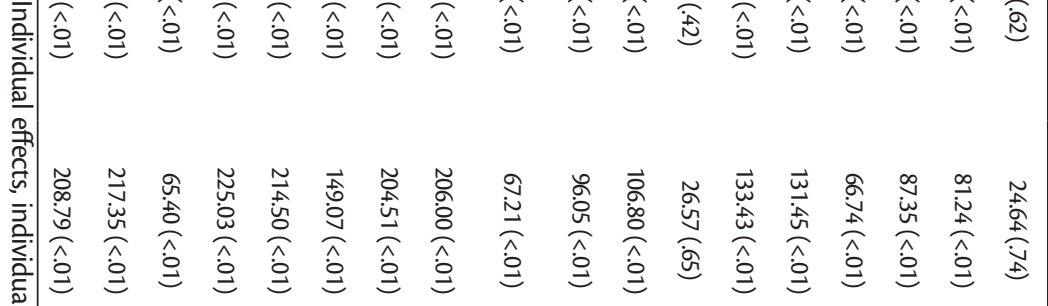
胥

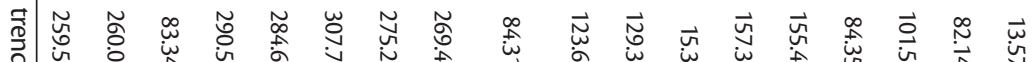
â

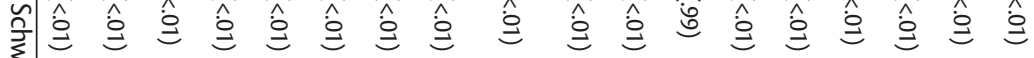
$\stackrel{3}{N}$

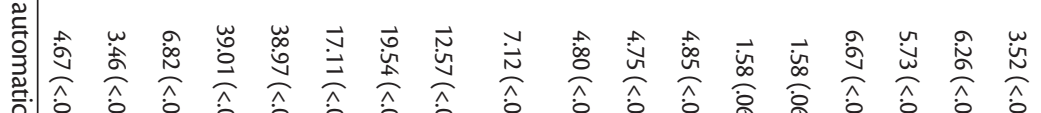

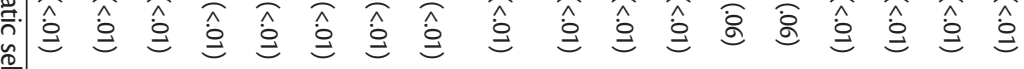

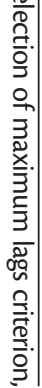

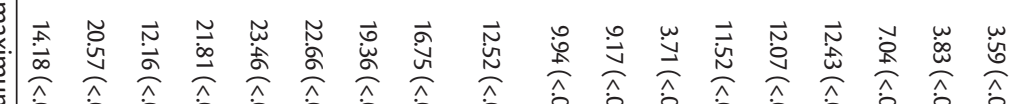

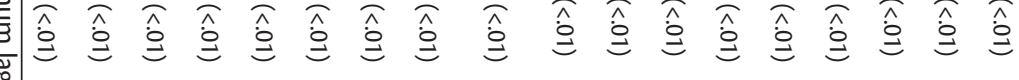

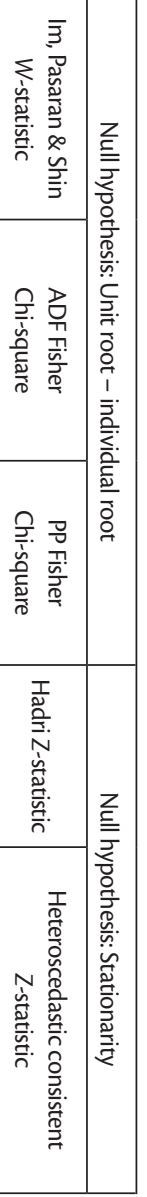


The problem with all the first generation panel unit root tests is that they assume cross-sectional independence. Therefore, the first generation panel unit root tests cannot be applied to panels where cross-sectional dependence cannot be excluded. Before using panel unit root test that can deal with cross-sectional dependence we highlight the cross-sectional dependence in our data. The null hypothesis is that there is no cross-section dependence. The results of all cross-sectional dependence tests are presented in Table 4.

Table 4. Cross-sectional dependence test statistic

\begin{tabular}{|c|c|c|c|c|}
\hline Variable & Breusch-Pagan LM & Pesaran scaled LM & Bias-corrected scaled LM & Pesaran CD \\
\hline GDP & $1070.34(<.01)$ & $66.61(<.01)$ & $66.15(<.01)$ & $24.53(<.01)$ \\
\hline FDI & $173.59(<.01)$ & $4.73(<.01)$ & $4.26(<.01)$ & $4.84(<.01)$ \\
\hline FDIP & $163.69(<.01)$ & $4.05(<.01)$ & $3.58(<.01)$ & $4.03(<.01)$ \\
\hline rGDP & $920.24(<.01)$ & $56.27(<.01)$ & $55.79(<.01)$ & $29.22(<.01)$ \\
\hline rFDI & $102.02(.56)$ & $-0.21(.84)$ & $-0.67(.50)$ & $-0.72(.47)$ \\
\hline rFDIP & $102.38(.55)$ & $-0.18(.86)$ & $-0.65(.52)$ & $-0.97(.33)$ \\
\hline LogGDP & $1077.49(<.01)$ & $67.11(<.01)$ & $66.64(<.01)$ & $24.56(<.01)$ \\
\hline LogFDI & $111.56(.31)$ & $0.45(.65)$ & $-0.02(.99)$ & $1.01(.31)$ \\
\hline LogFDIP & $134.03(.03)$ & $2.00(.05)$ & $1.53(.13)$ & $3.20(<.01)$ \\
\hline$\triangle \mathrm{GDP}$ & $940.47(<.01)$ & $57.65(<.01)$ & $57.18(<.01)$ & $29.56(<.01)$ \\
\hline$\Delta \mathrm{FDI}$ & $168.88(<.01)$ & $4.41(<.01)$ & $3.94(<.01)$ & $2.04(.04)$ \\
\hline$\Delta \mathrm{FDIP}$ & $161.91(<.01)$ & $3.93(<.01)$ & $3.46(<.01)$ & $1.92(.06)$ \\
\hline$\triangle \mathrm{rGDP}$ & $983.34(<.01)$ & $60.61(<.01)$ & $60.14(<.01)$ & $29.60(<.01)$ \\
\hline$\Delta \mathrm{rFDI}$ & $148.42(<.01)$ & $3.00(<.01)$ & $2.53(.01)$ & $-0.37(.71)$ \\
\hline$\Delta \mathrm{rFDIP}$ & $155.08(<.01)$ & $3.46(<.01)$ & $2.99(<.01)$ & $-0.54(.59)$ \\
\hline$\Delta$ LogGDP & $936.08(<.01)$ & $57.35(<.01)$ & $56.88(<.01)$ & $29.52(<.01)$ \\
\hline$\Delta$ LogFDI & $121.93(.12)$ & $1.17(.24)$ & $0.70(.48)$ & $0.70(.48)$ \\
\hline$\Delta$ LogFDIP & $133.52(.03)$ & $1.97(.05)$ & $1.50(.13)$ & $1.55(.12)$ \\
\hline
\end{tabular}

Note: Cross-section means were removed during computation of correlations. Degree of freedom for all tests is 105.

Source: Author's calculation

All the tests applied reject the null hypothesis of cross-sectional independence for level of three series (original series and logarithm transformed series) with one exception. Series LogFDI and $\Delta \mathrm{LogFDI}$ and also some of the growth rates and the first difference series show no cross-sectional dependence. While for these series we can trust the outcome of the first generation panel unit root tests results, results of cross-sectional independence tests for other series recommend use of the second generation panel unit root tests.

One of the tests that can deal with cross-sectional dependence is the Pesaran's CIPS test (Pesaran, 2007). We have use Stata v. 15 to apply Pesaran's CIPS test for unit roots in heterogeneous panels, 
i.e. in the presence of cross-section dependence. The null hypothesis is that all panels contain unit root, against the alternative hypothesis that some panels are stationary. Results of this tests are presented in Table 5.

Table 5. Pesaran's CIPS test statistic for unit roots in heterogeneous panels

\begin{tabular}{ccc}
\hline Variable & Without trend & With trend \\
\hline GDP & -0.82 & -1.99 \\
FDI & -3.60 & -3.54 \\
FDIP & -3.15 & 3.69 \\
rGDP & -2.80 & -2.83 \\
rFDI & -4.37 & -4.66 \\
rFDIP & -4.41 & -4.66 \\
LogGDP & -0.82 & -2.64 \\
LogFDI & -3.12 & -3.41 \\
LogFDIP & -3.27 & -3.59 \\
$\Delta$ GDP & -2.38 & -2.76 \\
$\Delta$ FDI & -5.44 & -5.51 \\
$\Delta$ FDIP & -5.31 & -5.59 \\
$\Delta$ rGDP & -4.22 & -3.97 \\
$\Delta$ rFDI & -5.51 & -5.49 \\
$\Delta$ rFDIP & -5.68 & -5.54 \\
$\Delta$ LogGDP & -2.75 & -2.51 \\
$\Delta$ LogFDI & -4.87 & -4.96 \\
$\Delta$ LogFDIP & -5.40 & -5.12 \\
\hline
\end{tabular}

Note: individual dynamics specifications in each regression is based on the Wald test of composite linear hypothesis about the parameters of the model. The $10 \%, 5 \%$ and $1 \%$ critical values for the model without trend are $-2.14,-2.26$ and -2.47 , and $-2.67,-2.78$ and -3.01 for the model with trend, respectively.

Source: Author's calculation

Pesaran CIPS test indicates for all but two series that the null hypothesis of unit root in all panels should be rejected at the 1\% significance level. Two exceptions are series GDP and LogGDP for which the Pesaran CIPS test indicated unit root in all panels.

Finally, Levin, Lin \& Chu and Breitung $(2000,2002)$ tests reject the null hypothesis of common unit root for all series at all significance levels (Table 3). We reached the same conclusion when using Im-Pasaran-Shin, ADF Fisher and PP Fisher tests, with two exceptions. Namely for series GDP and LogGDP these tests suggested that null hypothesis of unit root with individual trend can't be rejected. Contrary to the results of the above tests Hadri test and test based on heteroscedastic consistent Z-statistic reject for all series null hypothesis of stationarity. Possible reason why we are 
getting such mixed results could be that these tests have lower power in case of the structural break in time series, which is evident in case of GDP and LogGDP series.

Therefore, because of the strong cross-sectional dependence for some of the series, results of the Pesaran CPIS tests are more reliable than the results of the first generation panel unit root tests. In summary, we may say that all series both in level and the first difference are I(0), with GDP and LogGDP being the only exception. These two series are considered to be I(1).

\section{2 Panel cointegration test (ARDL model)}

Since unit root tests result suggested that GDP/LogGDP and FDI/LogFDI series are of different order of integration $(\mathrm{I}(1)$ and $\mathrm{I}(0)$ respectively), for these series cointegration tests based on ARDL model will be used.

The panel ARDL technique was selected to investigate the long-term and short-term cointegration correlations between GDP and FDI and extract the error correction version of the panel characteristics to identify the short-term dynamic. The panel ARDL method was preferred over more traditional cointegration techniques, such as Johansen (1991) cointegration test, because it could be used with the studied factors regardless of whether they were $\mathrm{I}(0), \mathrm{I}(1)$, or both $\mathrm{I}(0)$ and I(1). Using panel ARDL, both long-term and short-term coefficients are provided at once.

This approach is based on the use of the panel form of ARDL model proposed by Pesaran and Shin (1999) and Pesaran Shin and Smith (2001). The asymptotic features of these panels are different from the traditional panels' assumptions, with homogeneous slope parameters across the groups. They developed the pooled mean group (PMG) estimator, where the PMG assumes the combination of both pooling and averaging of the coefficients. In this respect, therefore, the intercept and slope parameters, and the error correction variances may all differ across the groups. To assess impact of the optimal lag length criteria on the ARDL results we have used both Akaike (1974) information criterion (AIC) and Schwarz (1978) information criterion (SIC). We have also estimated ARDL models for both original and logarithm transformation of the original series. Finally, ARDL models were estimated with two different trend specification: constant level and linear trend.

ARDL models based on logarithm transformation of the original series are preferred, for at least two reasons. First, most of the ARDL models estimated in literature are based on logarithm transformed series. Second, interpretation of the coefficients in such models is more intuitive. Coefficients in these models are elasticities, showing for how much will change the dependent variable for $1 \%$ change in independent variables. Therefore we are presenting all the results, but will comment only on those models with logarithm transformed series. 
V. Bilas: What is the Relationship Between FDI and Economic Growth? Evidence from EU15 Countries Zbornik Veleučilišta u Rijeci, Vol. 8 (2020), No .1, pp. 253-281

Table 6. Panel ARDL (PMG) estimation (dependent variable: GDP)

\begin{tabular}{lcccccc}
\hline \multirow{2}{*}{ Variable } & \multicolumn{5}{c}{ Constant } \\
\cline { 2 - 7 } & Coefficient & t-statistic & $P$-value & Coefficient & t-statistic & $P$-value \\
\hline \multirow{2}{*}{ FDI } & \multicolumn{7}{c}{ Long run equation } \\
\cline { 2 - 7 } & 4.9547 & 4.83 & $<.01$ & 1.9042 & 8.69 & $<.01$ \\
\cline { 2 - 7 } Cointegrating equation & -0.0494 & -1.37 & .17 & -0.2014 & -2.42 & .02 \\
$\Delta$ FDI & 0.1038 & 0.66 & .51 & -0.0548 & -0.43 & .67 \\
Trend & & & & $3.71 \mathrm{E}+09$ & 1.42 & .16 \\
Constant & $1.00 \mathrm{E}+11$ & 1.40 & .16 & $2.99 \mathrm{E}+11$ & 2.09 & .04 \\
\hline
\end{tabular}

Note: Schwarz criterion (SIC) was used for optimal lag length selection. ARDL $(1,1)$ model was selected.

Source: Author's calculation

Table 7. Panel ARDL (PMG) estimation (dependent variable: GDP)

\begin{tabular}{ccccccc}
\hline \multirow{2}{*}{ Variable } & \multicolumn{5}{c}{ Constant } & \multicolumn{3}{c}{ Linear trend } \\
\cline { 2 - 7 } & Coefficient & t-statistic & P-value & Coefficient & t-statistic & $P$-value \\
\cline { 2 - 7 } FDI & \multicolumn{5}{c}{ Long run equation } \\
\cline { 2 - 7 } & 4.8973 & 8.23 & $<.01$ & 4.3829 & 6.71 & $<.01$ \\
\cline { 2 - 7 } Cointegrating equation & -0.0700 & -1.42 & .16 & -0.0873 & -1.52 & .13 \\
$\Delta \mathrm{GDP}(-1)$ & 0.1695 & 1.41 & .16 & 0.0227 & 0.17 & .87 \\
$\Delta \mathrm{GDP}(-2)$ & -0.2367 & -2.94 & $<.01$ & -0.2943 & -2.32 & .02 \\
$\Delta \mathrm{GDP}(-3)$ & & & & -0.0451 & -0.54 & .59 \\
$\Delta \mathrm{FDI}$ & 0.0932 & 0.33 & .74 & 0.0598 & 0.23 & .82 \\
$\Delta \mathrm{FDI}(-1)$ & 0.1950 & 0.83 & .41 & 0.2609 & 0.96 & .34 \\
$\Delta \mathrm{FDI}(-2)$ & 0.0042 & 0.02 & .98 & 0.1826 & 0.66 & .51 \\
$\Delta \mathrm{FDI}(-3)$ & -0.1089 & -0.88 & .38 & 0.0241 & 0.16 & .87 \\
Trend & & & & $-1.03 \mathrm{E}+9$ & -0.89 & .38 \\
Constant & $1.20 \mathrm{E}+11$ & 1.20 & .23 & $1.13 \mathrm{E}+11$ & 1.40 & .16 \\
\hline
\end{tabular}

Note: Akaike criterion (AIC) was used for optimal lag length selection. $\operatorname{ARDL}(3,4)$ model with constant and $\operatorname{ARDL}(4,4)$ model with trend were selected. 
Table 8. Panel ARDL (PMG) estimation (dependent variable: GDP)

\begin{tabular}{ccccccc}
\hline \multirow{2}{*}{ Variable } & \multicolumn{5}{c}{ Constant } & \multicolumn{3}{c}{ Linear trend } \\
\cline { 2 - 7 } & Coefficient & t-statistic & P-value & Coefficient & t-statistic & $P$-value \\
\cline { 2 - 7 } FDIP & $9.51 \mathrm{E}+10$ & 4.60 & $<.01$ & $8.22 \mathrm{E}+10$ & 8.13 & $<.01$ \\
\cline { 2 - 7 } & & \multicolumn{7}{c}{ Short run equation } \\
\cline { 2 - 7 } Cointegrating equation equation \\
$\Delta$ FDIP & -0.0448 & -1.28 & .20 & -0.1280 & -2.28 & .02 \\
Trend & $-6.65 \mathrm{E}+8$ & -0.29 & .77 & $-4.71 \mathrm{E}+9$ & -1.60 & .11 \\
Constant & & & & $2.68 \mathrm{E}+9$ & 1.29 & .20 \\
\hline
\end{tabular}

Note: Schwarz criterion (SIC) was used for optimal lag length selection. ARDL $(1,1)$ model was selected.

Source: Author's calculation

Table 9. Panel ARDL (PMG) estimation (dependent variable: GDP)

\begin{tabular}{ccccccc}
\hline \multirow{2}{*}{ Variable } & \multicolumn{5}{c}{ Constant } & \multicolumn{3}{c}{ Linear trend } \\
\cline { 2 - 7 } & Coefficient & t-statistic & $P$-value & Coefficient & $t$-statistic & $P$-value \\
\cline { 2 - 7 } FDIP & $8.98 \mathrm{E}+10$ & 4.09 & $<.01$ & $6.70 \mathrm{E}+10$ & 7.00 & $<.01$ \\
\cline { 2 - 7 } & \multicolumn{7}{c}{ Lhort run equation } \\
\cline { 2 - 7 } Cointegrating equation equation \\
$\Delta$ SGDP(-1) & -0.0424 & -1.16 & .25 & -0.1408 & -2.16 & .03 \\
$\Delta$ SFIP & 0.1914 & 2.61 & $<.01$ & 0.1735 & 2.90 & $<.01$ \\
Trend & $-3.05 \mathrm{E}+8$ & -0.13 & .90 & $-4.03 \mathrm{E}+9$ & -1.44 & .15 \\
Constant & & & & $3.35 \mathrm{E}+9$ & 1.35 & .18 \\
\hline
\end{tabular}

Note: Akaike criterion (AIC) was used for optimal lag length selection. $\operatorname{ARDL}(2,1)$ model was selected.

Source: Author's calculation 
V. Bilas: What is the Relationship Between FDI and Economic Growth? Evidence from EU15 Countries Zbornik Veleučilišta u Rijeci, Vol. 8 (2020), No .1, pp. 253-281

Table 10. Panel ARDL (PMG) estimation (dependent variable: LogGDP)

\begin{tabular}{ccccccc}
\hline \multirow{2}{*}{ Variable } & \multicolumn{7}{c}{ Constant } & \multicolumn{5}{c}{ Linear trend } \\
\cline { 2 - 7 } & Coefficient & t-statistic & $P$-value & Coefficient & t-statistic & $P$-value \\
\cline { 2 - 7 } LogFDI & 0.8026 & 0.14 & .89 & 0.0292 & 7.34 & $<.01$ \\
\hline & & \multicolumn{5}{c}{ Short run equation } \\
\cline { 2 - 7 } Cointegrating equation \\
\cline { 2 - 7 }$\Delta$ LogFDI & -0.0005 & -0.52 & .61 & -0.1643 & -2.44 & .02 \\
Trend & 0.0020 & 1.66 & .10 & -0.0021 & -1.93 & .05 \\
Constant & & & & 0.0010 & 0.92 & .36 \\
\hline
\end{tabular}

Note: Schwarz criterion (SIC) was used for optimal lag length selection. ARDL(1,1) model was selected.

Source: Author's calculation

Table 11. Panel ARDL (PMG) estimation (dependent variable: LogGDP)

\begin{tabular}{ccccccc}
\hline \multirow{2}{*}{ Variable } & \multicolumn{5}{c}{ Constant } \\
\cline { 2 - 7 } & Coefficient & t-statistic & P-value & Coefficient & $t$-statistic & $P$-value \\
\cline { 2 - 7 } LogFDI & 0.0321 & 1.73 & .09 & 2.6923 & 0.05 & .96 \\
\cline { 2 - 7 } & \multicolumn{7}{c}{ Long run equation } \\
\cline { 2 - 7 } Cointegrating equation & -0.0477 & -2.27 & .02 & -0.0004 & 0.87 & .39 \\
$\Delta$ LogGDP(-1) & 0.2351 & 3.32 & $<.01$ & 0.2094 & 2.99 & $<.01$ \\
$\Delta$ LogFDI & 0.0011 & 0.95 & .34 & 0.0027 & 2.14 & .03 \\
Trend & & & & 0.0003 & 1.03 & .30 \\
Constant & 1.2669 & 2.34 & .02 & 0.0167 & 0.98 & .33 \\
\hline
\end{tabular}

Note: Akaike criterion (AIC) was used for optimal lag length selection. $\operatorname{ARDL}(2,1)$ model was selected.

Source: Author's calculation 
Table 12. Panel ARDL (PMG) estimation (dependent variable: LogGDP)

\begin{tabular}{|c|c|c|c|c|c|c|}
\hline \multirow{2}{*}{ Variable } & \multicolumn{3}{|c|}{ Constant } & \multicolumn{3}{|c|}{ Linear trend } \\
\hline & Coefficient & $t$-statistic & $P$-value & Coefficient & $t$-statistic & $P$-value \\
\hline & & & Long ru & uation & & \\
\hline \multirow{2}{*}{ LogFDIP } & 0.1226 & 3.74 & $<.01$ & 0.4398 & 5.76 & $<.01$ \\
\hline & \multicolumn{6}{|c|}{ Short run equation } \\
\hline Cointegrating equation & -0.0523 & -1.95 & .05 & -0.0408 & -1.71 & .09 \\
\hline$\Delta$ LogFDIP & 0.0006 & 0.19 & .85 & -0.0064 & -1.19 & .23 \\
\hline Trend & & & & -0.0005 & -0.49 & .62 \\
\hline Constant & 1.4660 & 1.95 & .05 & 1.13 & 1.73 & .09 \\
\hline
\end{tabular}

Note: Schwarz criterion (SIC) was used for optimal lag length selection. ARDL $(1,1)$ model was selected.

Source: Author's calculation

Table 13. Panel ARDL (PMG) estimation (dependent variable: LogGDP)

\begin{tabular}{ccccccc}
\hline \multirow{2}{*}{ Variable } & \multicolumn{5}{c}{ Constant } & \multicolumn{5}{c}{ Linear trend } \\
\cline { 2 - 7 } & Coefficient & t-statistic & P-value & Coefficient & t-statistic & $P$-value \\
\cline { 2 - 7 } LogFDIP & 0.1350 & 3.33 & $<.01$ & 0.3245 & 4.87 & $<.01$ \\
\cline { 2 - 7 } & \multicolumn{7}{c}{ Long run equation } \\
\cline { 2 - 7 } Cointegrating equation & -0.0595 & -2.48 & .01 & -0.0443 & -2.12 & .04 \\
$\Delta$ LogGDP(-1) & 0.2382 & 2.71 & $<.01$ & 0.1460 & 2.07 & .04 \\
$\Delta$ LogGDP(-2) & -0.2855 & -6.53 & $<.01$ & & & \\
$\Delta$ LogFDIP & 0.0005 & 0.13 & .90 & -0.0034 & -0.99 & .32 \\
Trend & & & & $1.58 \mathrm{E}-5$ & 0.03 & .98 \\
Constant & 1.65 & 2.44 & .02 & 1.22 & 2.14 & .04 \\
\hline
\end{tabular}

Note: Akaike criterion (AIC) was used for optimal lag length selection. $\operatorname{ARDL}(3,1)$ model with constant and $\operatorname{ARDL}(2,1)$ model with trend were selected.

Source: Author's calculation

The coefficient of the error correction term (ECT) goes in line with the underlying convergence assumptions in order to validate the long-run equilibrium nature of the model. These include that the ECT be negative, significant, and less than one (Pesaran et al., 1999). We are commenting on the results of models based on Akaike information criterion presented in Tables 11 and 13. The reason is that the Schwarz information criterion tends to underestimate optimal lag length. 
For instance Akaike criterion suggested $\operatorname{ARDL}(3,1)$, while Schwarz criterion suggested $\operatorname{ARDL}(1,1)$ model. As a consequence of such underestimation there could be some residual autocorrelation. While Akaike information criterion tends to overestimate the optimal lag length, this has less serious consequence on the reliability of the estimated panel ARDL model.

The cointegrating equations (model with trend: -0.0443 and model with constant: -0.0595 ) in Table 13 explain that the rate of adjustment back to (long-run) equilibrium is $4.43 \%$ (model with trend) and 5.95\% (model with constant) which are significant at $4 \%$ and $1 \%$ significance level respectively. In the short-run, only the coefficients of each of $\operatorname{LogGDP}(-1)$ and $\log G D P(-2)$ are each significantly related to $\log G D P$, at less than $1 \%$ significance level.

More mixed results are presented in Table 11 for LogFDI series. Here we have the cointegrating equation (model with constant: -0.0477 ) explains that the rate of adjustment back to (longrun) equilibrium is $4.77 \%$ which are significant at $2 \%$ significance level. However, the ECT in the model with trend is not statistically significant, though it is negative and less than one. In the short-run, only the coefficient of $\operatorname{LogGDP}(-1)$ is significantly related to $\log G D P$, at less than $1 \%$ significance level.

The panel ARDL is a long-run estimate of the equilibrium analysis, and therefore the long-run coefficients are usually given higher importance. The long-run coefficients are all positive, but not all of them are statistically significant. For instance the long-run coefficient for LogFDI $(0.029)$ is statistically significant only in the model with trend (Table 9) but not in other models (Table 11). In case of LogFDIP series long-run coefficients are statistically significant in all four models in Tables 12 and 13, varying between 0.1226 and 0.4398 . These coefficients indicate that $1 \%$ increase in LogFDIP (logarithm of FDI to GDP) increases LogGDP between $0.1226 \%$ and $0.4398 \%$.

Therefore, the cointegration test based on panel ARDL (PMG) model confirm that there are long-term relationship between LogGDP, LogFDI and LogFDIP series in case of 15 "old" European Union countries for the period being investigated (2002-2018).

\subsection{Granger causality analysis}

We tested whether there is a causal relationship among the variables using the panel Granger noncausality test developed by Dumitrescu and Hurlin (2012). The null hypothesis is that variable X does not homogeneously cause variable $Y$, against the alternative hypothesis that $X$ does Grangercause $Y$ for at least one panel. Table 14 gives the results of this test. 
Table 14. Dumitrescu-Hurlin panel causality test

\begin{tabular}{ccccc}
\hline Null hypothesis & $\bar{W}$ & $\bar{Z}$ & $\tilde{Z}$ & Decision* $^{*}$ \\
\hline rGDP does not Granger-cause FDI & 2.58 & $4.34(.07)$ & $2.55(.07)$ & No causality \\
FDIP does not Granger-cause rGDP & 1.50 & $1.36(.31)$ & $0.51(.61)$ & No causality \\
rGDP does not Granger-cause FDIP & 2.46 & $4.01(.09)$ & $2.33(.09)$ & No causality \\
LogFDI does not Granger-cause $\Delta$ LogGDP & 1.98 & $2.68(.09)$ & $1.52(.10)$ & No causality \\
$\Delta$ LogGDP does not Granger-cause LogFDI & 1.63 & $1.72(.20)$ & $0.83(.27)$ & No causality \\
LogFDIP does not Granger-cause $\Delta$ LogGDP & 1.22 & $0.33(.75)$ & $-0.15(.92)$ & No causality \\
$\Delta$ LogGDP does not Granger-cause LogFDIP & 2.46 & $3.99(.04)$ & $2.45(.04)$ & Causality \\
LogFDI does not Granger-cause LogGDP & 1.66 & $1.82(.26)$ & $0.97(.39)$ & No causality \\
LogGDP does not Granger-cause LogFDI & 2.30 & $3.55(.09)$ & $2.24(.09)$ & No causality \\
LogFDIP does not Granger-cause LogGDP & 1.46 & $1.25(.38)$ & $0.56(.56)$ & No causality \\
LogGDP does not Granger-cause LogFDIP & 1.66 & $1.82(.40)$ & $0.97(.50)$ & No causality \\
$\Delta$ LogFDI does not Granger-cause $\Delta$ LogGDP & 1.79 & $2.17(.15)$ & $1.56(.28)$ & No causality \\
$\Delta$ LogGDP does not Granger-cause $\Delta$ LogFDI & 1.64 & $1.77(.01)$ & $0.87(.02)$ & Causality \\
$\Delta$ LogFDIP does not Granger-cause $\Delta$ LogGDP & 1.13 & $0.36(.77)$ & $-0.13(.92)$ & No causality \\
$\Delta$ LogGDP does not Granger-cause $\Delta$ LogFDIP & 1.89 & $2.42(.13)$ & $1.33(.19)$ & No causality \\
\hline
\end{tabular}

Note: P-values were computed using 100 bootstrap replications and provided in the brackets. BIC criterion used to decide on the optimal number of lags. * Decision was made based on the $5 \%$ significance level.

Source: Author's calculation

According to Table 14 there is no causal relationship between any two variables considered with only two exceptions. When investigated the causal relationship between GDP growth rate $(\Delta \mathrm{LogGDP})$ and FDI growth rate $(\Delta \mathrm{LogFDI})$ we can say that GDP growth rate cause FDI growth rate at least of $2 \%$ significance level, while FDI growth rate does not cause GDP growth rate. Thus, there is a unidirectional causal relationship between the GDP growth rate and FDI growth rate. Similarly, there is a unidirectional causal relationship between the GDP growth rate and LogFDI at $4 \%$ significance level.

Expectation is that if there is a cointegration between two series then they are also causally related. However, mixed results of cointegration test based on ARDL (PMG) model and the DumitrescuHurlin panel causality test do not confirm this, which could be caused by lower power of these tests and weak relationship between series. Therefore we can say that there is only a weak evidence of the positive impact FDI has on GDP growth in the "old" European Union member countries.

\section{CONCLUSION}

The aim of this paper was to examine the relationship between FDI and economic growth in EU15 countries over the period 2002-2018. Based on the conducted analysis following conclusions can be drawn. Results of the Pesaran CIPS panel unit root test indicated that all series considered 
are stationary, i.e. I(0), with two exceptions. This test indicated that series GDP and LogGDP are with unit root, i.e. I(1). Since level of GDP series is I(1) and levels of FDI and FDIP are I(0) only the ARDL modelling approach to cointegration could be used, because this approach allows series to be different order of integration. Estimated panel ARDL (PMG) model found some evidence that there are long-run equilibrium between LogGDP, LogFDI and LogFDIP series. The rate of adjustment back to equilibrium is between $4.43 \%$ and $5.95 \%$. The long-run coefficients are all positive, but not all of them are statistically significant. For instance the long-run coefficient for LogFDI (0.029) is statistically significant only in the model with trend, but not in other models. In case of LogFDIP series long-run coefficients are statistically significant in all four models, varying between 0.1226 and 0.4398 . These coefficients indicate that $1 \%$ increase in LogFDIP (logarithm of FDI to GDP) increases LogGDP between $0.1226 \%$ and $0.4398 \%$. Results of Dumitrescu-Hurlin panel causality test indicated that there is only unidirectional causal relationship from GDP growth rate to FDI growth rate, and from GDP growth rate to LogFDIP. There is no other causal relationship between any other two variables considered. Conclusively, there is only a weak evidence that FDI had statistically significant impact on the GDP in EU15 countries for the period being investigated. Despite its insights and accomplishments, this research has some limitations, for example number of variables which could have impact on FDI and GDP should be extended. Therefore, it is advised to include in future research other variables (for example, institutional quality, human capital, market size, unit labour costs, openness of the economy, etc.). There is also a need to extend the period of research and/or to use quarterly/monthly data if possible in order to increase the number of observations. Also, single-country studies are needed, due to the heterogeneous relationship between FDI and growth.

\section{REFERENCES}

Akaike, H. (1974) "A new look at the statistical model identification", IEEE Transactions on Automatic Control, 19(6), pp. 716-723. http://dx.doi.org/10.1109/tac.1974.1100705

Alfaro, L., Chanda, A., Kalemli-Ozcan, S., Sayek, S. (2010) “Does Foreign Direct Investment Promote Economic Growth? Exploring the Role of Financial Markets on Linkages?" Journal of Development Economics, 91(2), pp. 242-256. http:// dx.doi.org/10.1016/j.jdeveco.2009.09.004

Angelopoulou, A., Liargovas, P. (2014) "Foreign Direct Investment and Growth: EU, EMU, and Transition Economies", Journal of Economic Integration, 29(3), pp. 470-495. http://dx.doi.org/10.11130/jei.2014.29.3.470

Bilas, V. (2007) "Regional economic integrations and capital movement - measuring the level of capital mobility", Zbornik radova Ekonomskog fakulteta u Rijeci, 25(2), pp. 269-290

Borensztein, E., De Gregorio, J., Lee, J-W. (1998) “How does foreign direct investment affect economic growth?”, Journal of International Economics, 45(1998), pp. 115-135

Breitung, J. (2000). “The Local Power of Some Unit Root Tests for Panel Data," in B. Baltagi (ed.), Advances in Econometrics, (15): Nonstationary Panels, Panel Cointegration, and Dynamic Panels, Amsterdam: JAI Press, pp. 161-178. http:// dx.doi.org/10.1016/s0731-9053(00)15006-6

Breitung, J. (2002). "Nonparametric tests for unit roots and cointegration", Journal of Econometrics, 108(2), pp. 343-363. http://dx.doi.org/10.1016/s0304-4076(01)00139-7 
Carbonell, J. B., Werner, R. A. (2018) “Does Foreign Direct Investment Generate Economic Growth? A New Empirical Approach Applied to Spain”, Economic Geography, 94(4), pp. 425-456. http://dx.doi.org/10.1080/00130095.2017 .1393312

Carstensen, K., Toubal, F. (2004) "Foreign direct investment in Central and Eastern European countries: a dynamic panel analysis", Journal of Comparative Economics, 32(1), pp. 3-22. https://doi.org/10.1016/j.jce.2003.11.001

Chowdhury, A., Mavrotas, G. (2006) “FDI and Growth: What Causes What?", The World Economy, 29(1), pp. 9-19. http:// dx.doi.org/10.1111/j.1467-9701.2006.00755.x

De Mello, L. R. (1997) “Foreign direct investment in developing countries and growth: A selective survey", The Journal of Development Studies, 34(1), pp. 1-34. http://dx.doi.org/10.1080/00220389708422501

De Mello, L. R. (1999) “Foreign direct investment-led growth: evidence from time series and panel data”, Oxford Economic Papers, 51(1), pp. 133-151. http://dx.doi.org/10.1093/oep/51.1.133

Dhakal, D., Mixon, F., Upadhyaya, K. (2007) "Foreign direct investment and transition economies: empirical evidence from a panel data estimator", Economics Bulletin, 6(33), pp. 1-9

Dickey, D. A., Fuller, W. A. (1981) “Likelihood ratio statistics for autoregressive time series with a unit root", Econometrica, 49(4), pp. 1057-1072. http://dx.doi.org/10.2307/1912517

Dickey, D. A., W. A. Fuller (1979) “Distribution of the Estimators for Autoregressive Time Series with a Unit Root", Journal of the American Statistical Association, 74(366a), pp. 427-431. http://dx.doi.org/10.1080/01621459.1979.10482531

Dumitrescu, E. I., Hurlin, C. (2012) "Testing for Granger non-causality in heterogeneous panels", Economic Modelling, 29(4), pp. 1450-1460. http://dx.doi.org/10.1016/j.econmod.2012.02.014

Ekananda, M., Parlinggoman, D. J. (2017) "The Role of High-Tech Exports and of Foreign Direct Investments (FDI) on Economic Growth", European Research Studies Journal, XX(4A), pp. 194-212.

Gürsoy, F., Sekreter, A., Kalyoncu, H. (2013) „FDl and Economic Growth Relationship Based on Cross-Country Comparison“, International Journal of Economics and Financial Issues, 3(2), pp. 519-524

Hadri, K. (2000) "Testing for Stationarity in Heterogeneous Panel Data", Econometric Journal, 3(2), pp. 148-161. http:// dx.doi.org/10.1111/1368-423x.00043

Hlavacek, P., Bal-Domanska, B. (2016) “Impact of Foreign Direct Investment on Economic Growth in Central and Eastern European Countries", Inzinerine Ekonomika-Engineering Economics, 27(3), pp. 294-303. http://dx.doi.org/10.5755/ j01.ee.27.3.3914

Hunady, J., Orviska, M. (2014) “Determinants of Foreign Direct Investment in EU countries - Do Corporate Taxes Really Matter?", Procedia Economics and Finance, 12, pp. 243-250. http://dx.doi.org/10.1016/s2212-5671(14)00341-4

lamsiraroj, S., Doucouliagos, H. (2015) “Does growth attract FDI?", Kiel Institute for the World Economy, Economics Discussion Papers, No. 2015-18. http://dx.doi.org/10.5018/economics-ejournal.ja.2015-19

Im, K. S., M. H. Pesaran, Y. Shin (2003) "Testing for Unit Roots in Heterogeneous Panels", Journal of Econometrics, 115(1), pp. 53-74. http://dx.doi.org/10.1016/s0304-4076(03)00092-7

lqbal, N., Ahmad, N., Haider, Z., Anwar, S. (2013) “Impact of foreign direct investment (FDI) on GDP: A Case study from Pakistan", International Letters of Social and Humanistic Sciences, 16, pp. 73-80. http://dx.doi.org/10.18052/www. scipress.com/ilshs. 16.73

Jirasavetakul, L-B. F., Rahman, J. (2018) “Foreign Direct Investment in New Member States of the EU and Western Balkans: Taking Stock and Assessing Prospects”, IMF Working Paper, 18(187), p.1. http://dx.doi.org/10.5089/97814843733 23.001

Johansen, S. (1991) "Estimation and Hypothesis Testing of Cointegration Vectors in Gaussian Vector Autoregressive Models", Econometrica, 59 (6), pp. 1551-1580. http://dx.doi.org/10.2307/2938278

Jude, C., Pop Silaghi, M. I. (2016) “Employment effects of foreign direct investment: New evidence from Central and Eastern European countries", International Economics, 145(2016), pp. 32-49. https://doi.org/10.1016/j.inteco.2015.02.003 


\section{Bilas: What is the Relationship Between FDI and Economic Growth? Evidence from EU15 Countries Zbornik Veleučilišta u Rijeci, Vol. 8 (2020), No .1, pp. 253-281}

Kersan-Skabic, I. (2013) "Institutional Development as a Determinant of FDI Attractiveness in Southeast Europe", Drustvena istrazivanja, 22(2), pp. 215-235. http://dx.doi.org/10.5559/di.22.2.01

Kikerkova, I. et al. (2018) "Vector Error Correction Model on FDI and their Impact in the Republic of Macedonia", Zagreb International Review of Economics \& Business, 21(2), pp. 19-35. http://dx.doi.org/10.2478/zireb-2018-0012

Kurecic, P., Kozina, G. (2017) "The Correlation between the FDI and the GDP in the EU15 Member States in the period 1980-2014", Tehnicki vjesnik, 24(2), pp. 521-524. http://dx.doi.org/10.17559/tv-20150920174332

Levin, A., Lin, C. F., Chu, C. (2002) "Unit Root Tests in Panel Data: Asymptotic and Finite-Sample Properties", Journal of Econometrics, 108(1), pp. 1-24. http://dx.doi.org/10.1016/s0304-4076(01)00098-7

Mahmoodi, M., Mahmoodi, E. (2016) "Foreign direct investment, exports and economic growth: evidence from two panels of developing countries", Economic Research-Ekonomska Istrazivanja, 29(1), pp. 938-949. http://dx.doi.org/1 $0.1080 / 1331677 \times .2016 .1164922$

Ozturk, I. (2007) “Foreign Direct Investment - Growth Nexus: A Review of the Recent Literature", International Journal of Applied Econometrics and Quantitative Studies, 4-2, pp. 79-98

Pesaran, M. H. (2007) "A simple panel unit root test in the presence of cross-section dependence", Journal of Applied Econometrics, 22(2), pp. 265-312. http://dx.doi.org/10.1002/jae.951

Pesaran, M. H., Shin, Y. (1999) "An Autoregressive Distributed-Lag Modelling Approach to Cointegration Analysis," in Strøm, S. (ed.) Econometrics and Economic Theory in the 20th Century: The Ragnar Frisch Centennial Symposium. Cambridge: Cambridge University Press (Econometric Society Monographs), pp. 371-413. http://dx.doi. org/10.1017/ccol521633230.011

Pesaran, M. H., Shin, Y., Smith, R. J. (2001) "Bounds testing approaches to the analysis of level relationships", Journal of Applied Econometrics, 16(3), pp. 289-326. http://dx.doi.org/10.1002/jae.616

Rahaman, A., Chakraborty, S. (2015) "Effects of Foreign Direct Investment on GDP: Empirical Evidence from Developing Country", Advances in Economics and Business, 3(12), pp. 587-592

Sârbu, M-A., Carp, L. (2015) “The Impact of Foreign Direct Investment on Economic Growth: The Case of Romania”, Economica, 11(4), pp. 127-137

Schmitt, D., Alexiou, C. (2016) "On the FDI-led Growth Hypothesis: Empirical Evidence from Ireland", The Empirical Economics Letters, 15(2), pp. 135-144

Schwarz, G. E. (1978) "Estimating the dimension of a model", The Annals of Statistics, 6 (2), pp. 461-464. http://dx.doi. org/10.1214/aos/1176344136

Sokang, K. (2018) "The Impact of Foreign Direct Investment on the Economic Growth in Cambodia: Empirical Evidence", International Journal of Innovation and Economic Development, 4(5), pp. 31-38. http://dx.doi.org/10.18775/ ijied.1849-7551-7020.2015.45.2003

Suliman, A. H., Elian, M. I., Ali, H. E. (2018) “Endogenous Specification of FDI and Economic Growth: Cross-Economies' Evidence", International Journal of Business, 23(1), pp. 89-109

Tang, D. (2015) "Has the Foreign Direct Investment Boosted Economic Growth in the European Union Countries?", Journal of International and Global Economic Studies, 8(1), pp. 21-50

UNCTAD (2018) World Investment Report 2018. New York and Geneva: United Nations

UNCTAD (2019) World Investment Report 2019. New York and Geneva: United Nations 


\section{ANNEX 1. LINE GRAPHS}

Line graphs for all variables in Table 1 are presented in Figures 1 to 12. The first three figures show the first three series: GDP, FDI and FDIP, the next three annual growth rates, then three natural logarithm series, and the last three figures display the first difference of the logarithm series.

\section{Graph 1. GDP time series}

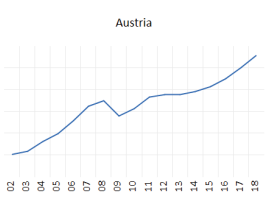

France

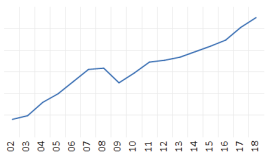

Italy

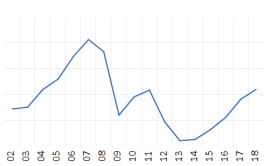

Spain

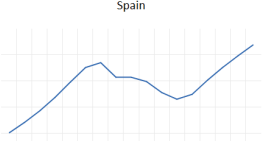

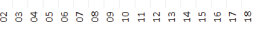

Real gross domestic product (constant 2011 international \$

Belgium

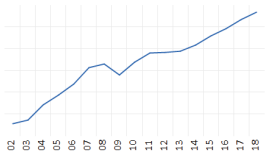

Germany

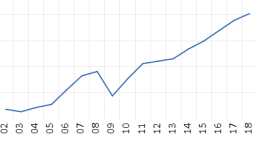

Luxembourg

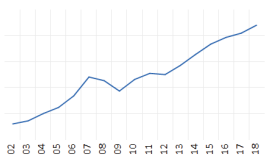

Sweden

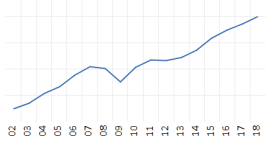

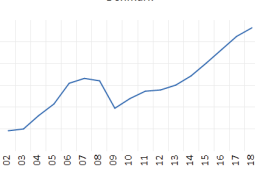

Greece

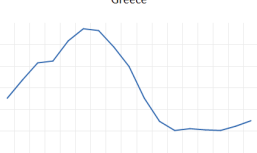

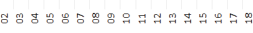

Netherlands

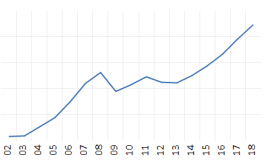

United Kingdom

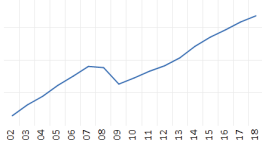

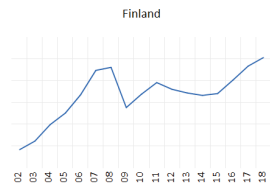

Ireland

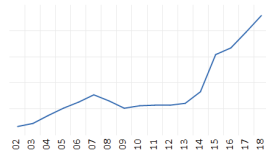

portuga

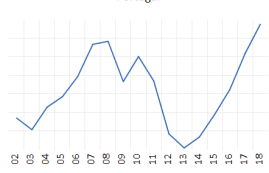


V. Bilas: What is the Relationship Between FDI and Economic Growth? Evidence from EU15 Countries Zbornik Veleučilišta u Rijeci, Vol. 8 (2020), No .1, pp. 253-281

\section{Graph 2. FDI time series}

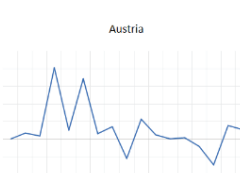

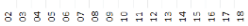
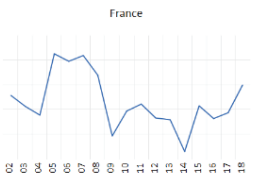

Italy

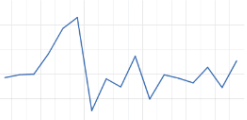

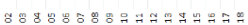

Spain
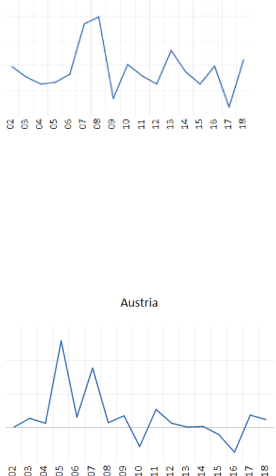

France

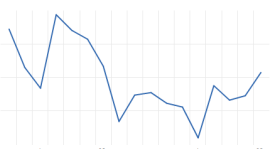

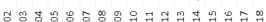

Italy

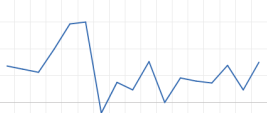

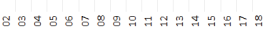
Spain

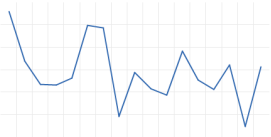

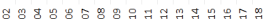

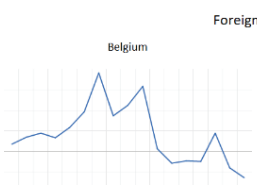

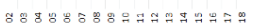
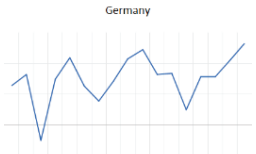

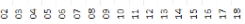

Luxembourg

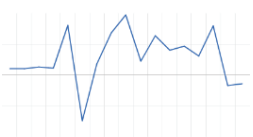

Sweden

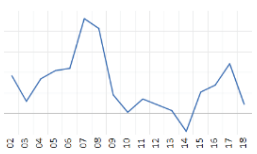

\section{Graph 3. FDIP time series}

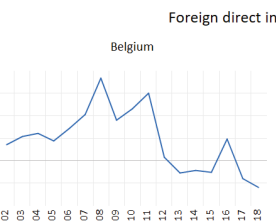

Germany

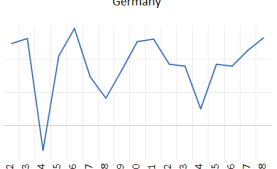

Luxembourg

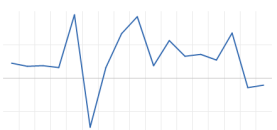

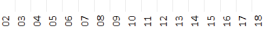
sweden

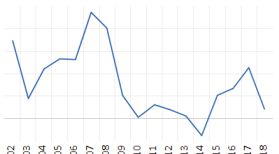

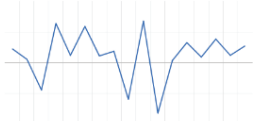

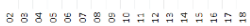

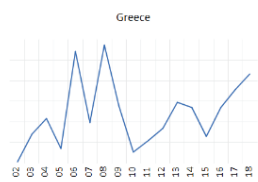

Netherlands

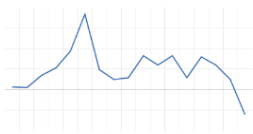

United Kingdom

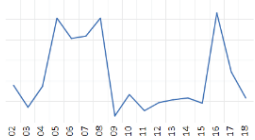

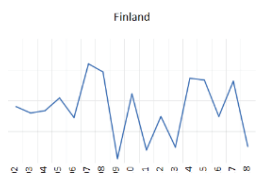

Ireland

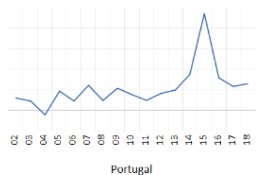

Portupal

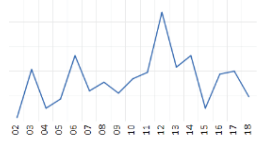

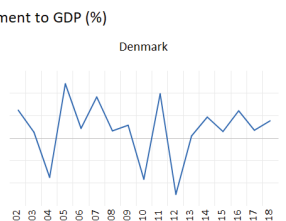

Greece

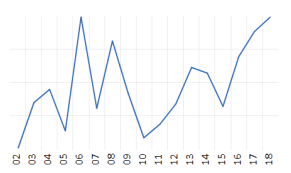

Netherlands

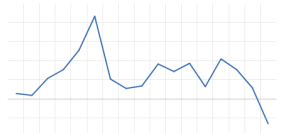

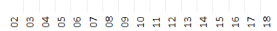
United Kingdom

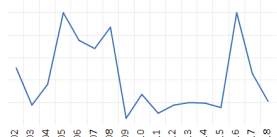

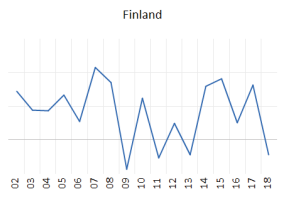

Ireland

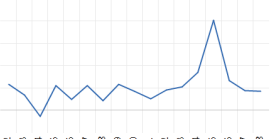

Portugal

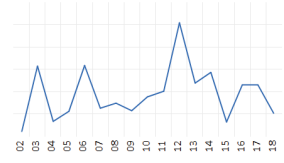


V. Bilas: What is the Relationship Between FDI and Economic Growth? Evidence from EU15 Countries Zbornik Veleučilišta u Rijeci, Vol. 8 (2020), No. 1, pp. 253-281

\section{Graph 4. GDP growth rate}

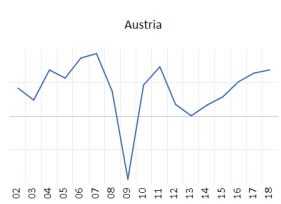

France

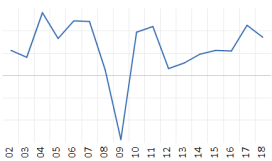

Italy

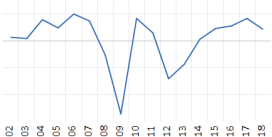

spain

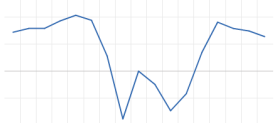

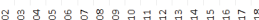

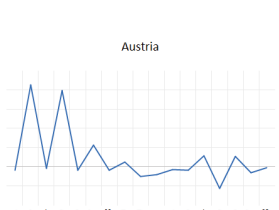

France

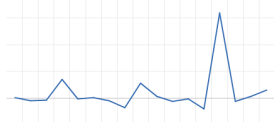

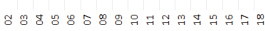

Italy

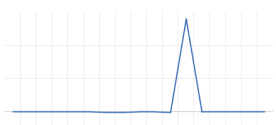

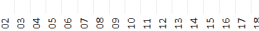

Spain

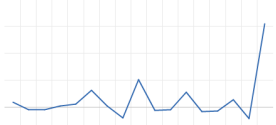

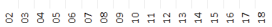

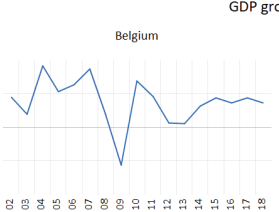

Germany

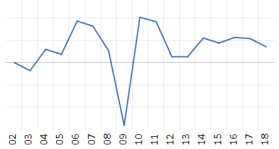

Luxembourg

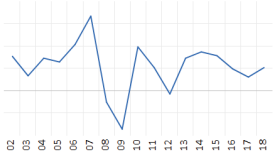

Sweden

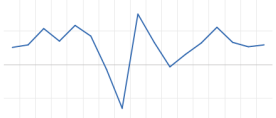

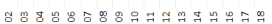

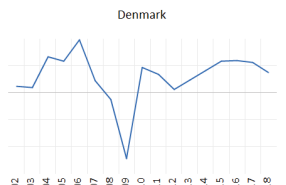

Greece

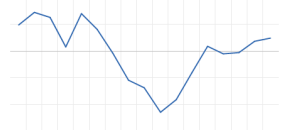

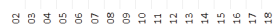

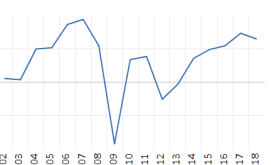

United Kingdom

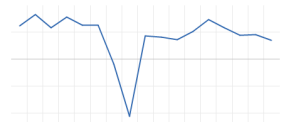

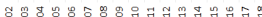

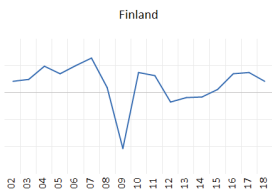

Ireland

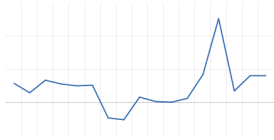

Portuga

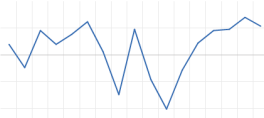

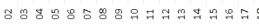

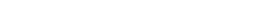

\section{Graph 5. FDI growth rate}

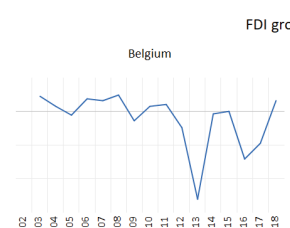

Germany

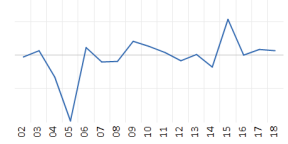

Luxembourg

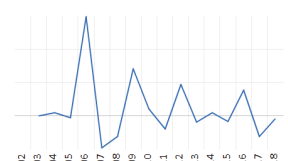

Sweden

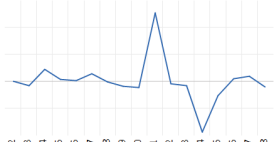

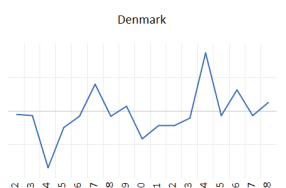

Greece

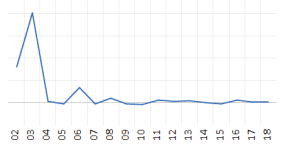

Netherlands

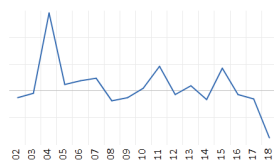

United Kingdom

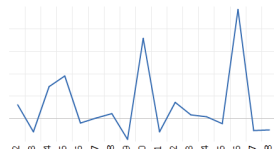

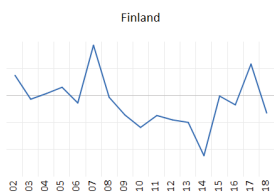

Ireland

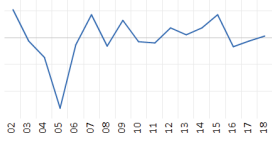

Portugal

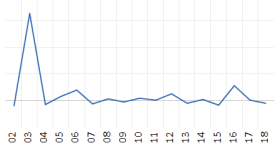


V. Bilas: What is the Relationship Between FDI and Economic Growth? Evidence from EU15 Countries Zbornik Veleučilišta u Rijeci, Vol. 8 (2020), No .1, pp. 253-281

\section{Graph 6. FDIP growth rate}

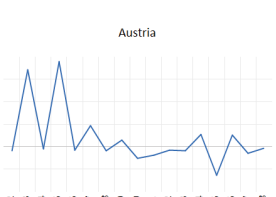

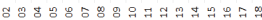

France

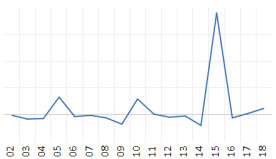

Italy

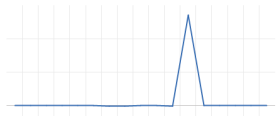

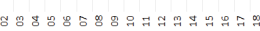

Spain

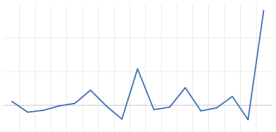

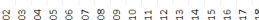

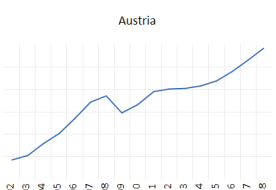

France

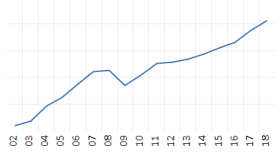

Italy

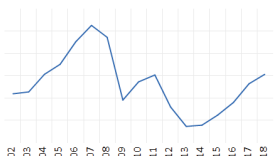

Spain

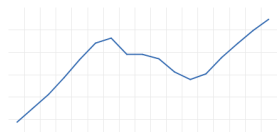

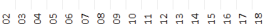

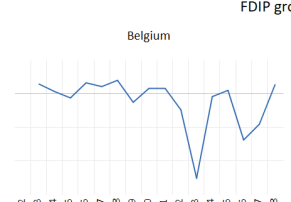

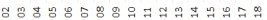

Germany

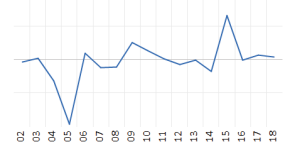

Luxembourg

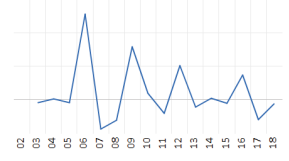

sweden

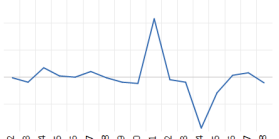

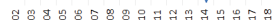

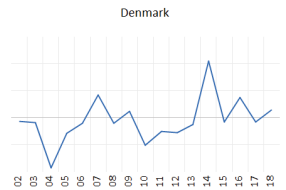

Greece

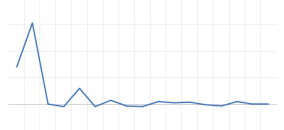

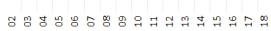

Netherlands

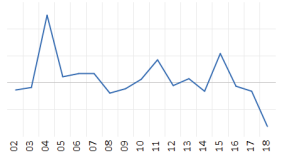

United Kingdom

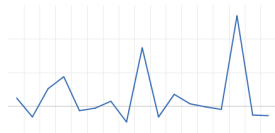

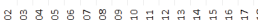

\section{Graph 7. LogGDP time series}

Log of Real gross domestic product (constant 2011 international \$)

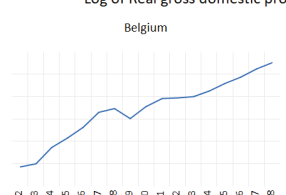

Germany

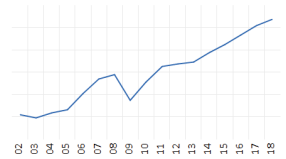

Luxembourg

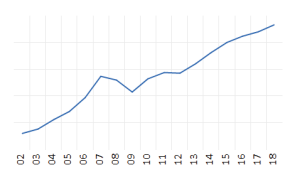

Sweden

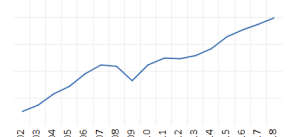

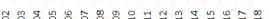

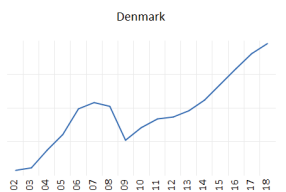

Greece

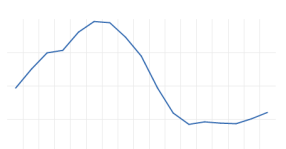

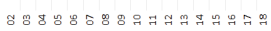

Netherlands

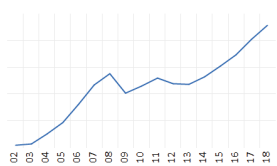

United Kingdom

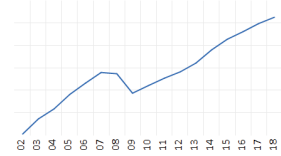

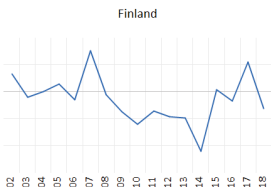

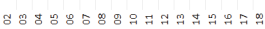

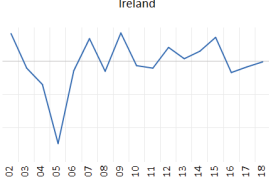

Portugal

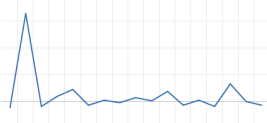

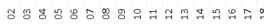
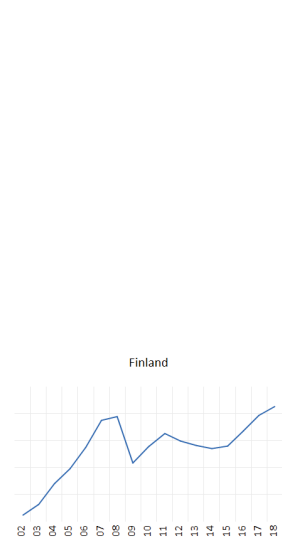

Ireland

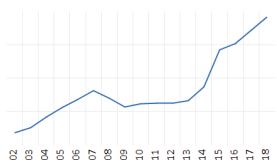

portugal

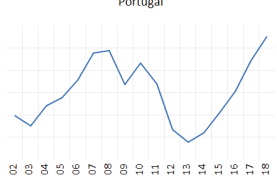


V. Bilas: What is the Relationship Between FDI and Economic Growth? Evidence from EU15 Countries Zbornik Veleučilišta u Rijeci, Vol. 8 (2020), No. 1, pp. 253-281

\section{Graph 8. LogFDI time series}

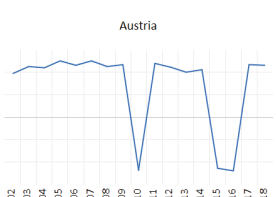

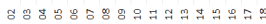
France

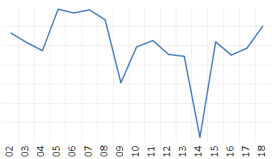

Italy

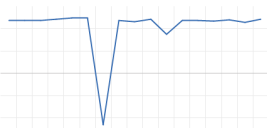

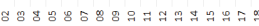
Spain

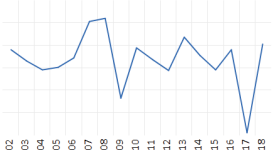

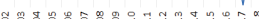

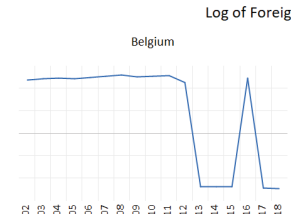

Germany

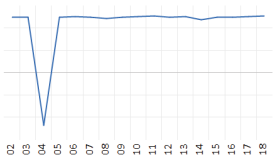

Luxembourg
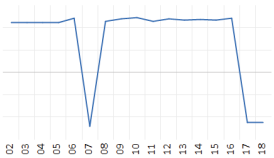

Sweden

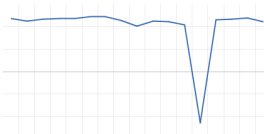

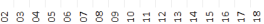

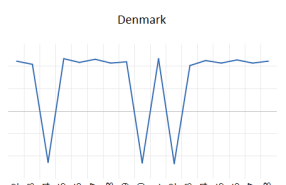

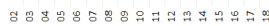
Greece

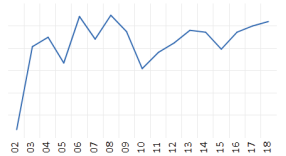

Netherlands

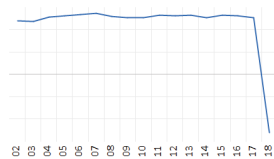

United Kingdom

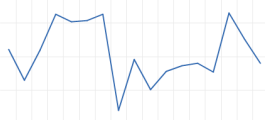

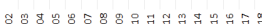

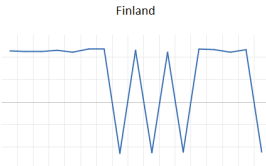

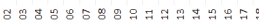
Ireland

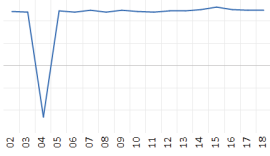

Portugal

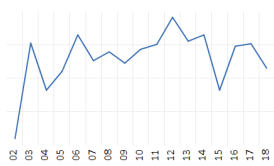

\section{Graph 9. LogFDIP time series}
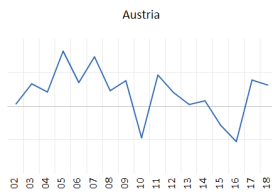

France

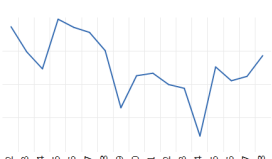

Italy

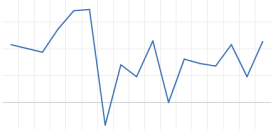

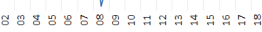

Spain

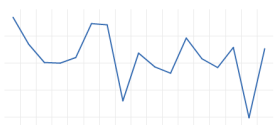

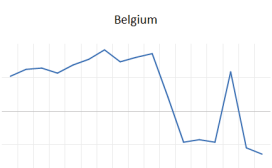

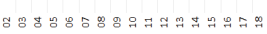

Germany

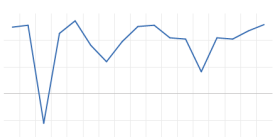

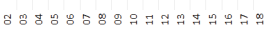
Luxembourg

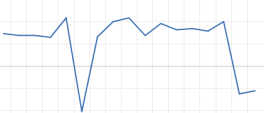

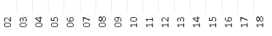
Sweden

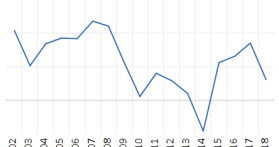

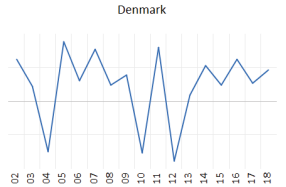

Greece

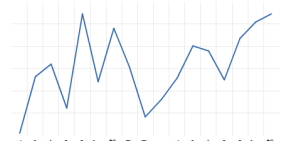

Netherlands

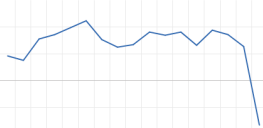

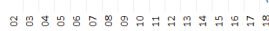

United Kingdom

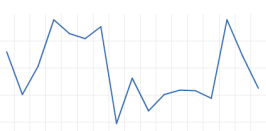

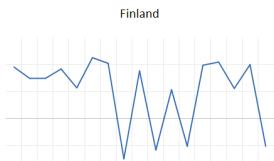

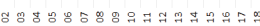

Ireland

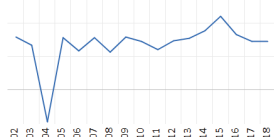

Portugal

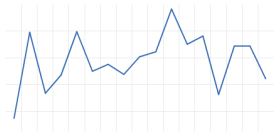

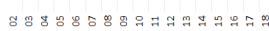

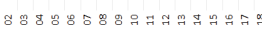


V. Bilas: What is the Relationship Between FDI and Economic Growth? Evidence from EU15 Countries Zbornik Veleučilišta u Rijeci, Vol. 8 (2020), No .1, pp. 253-281

\section{Graph 10. $\triangle$ GDP time series}

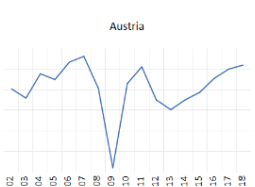

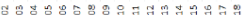

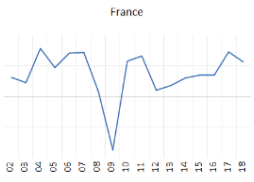

Italy

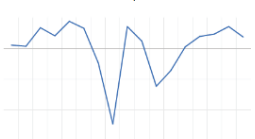

Spain

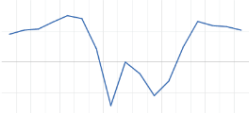

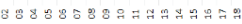

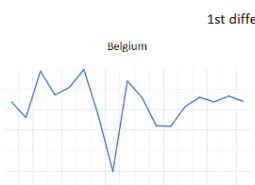

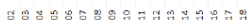
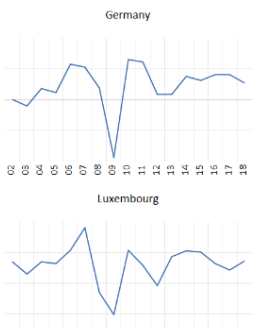

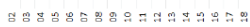
Sweden

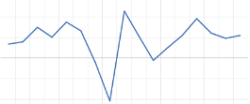

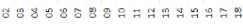

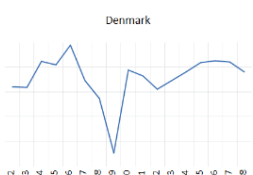

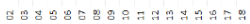
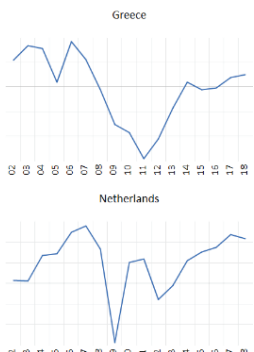

United Kingdom

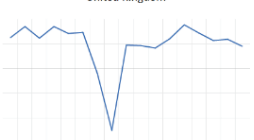

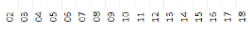

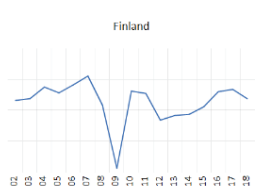

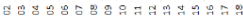

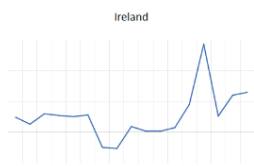

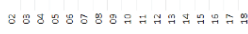

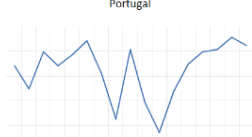

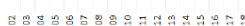

\section{Graph 11. $\Delta \mathrm{FDI}$ time series}

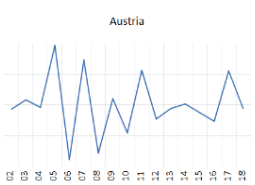

France

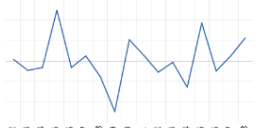

Italy

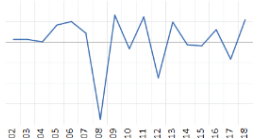

spain

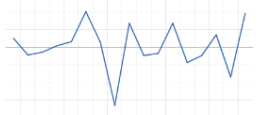

1st difference of FDl series

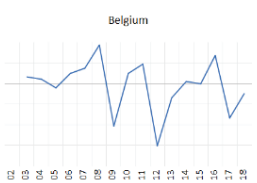

Germany

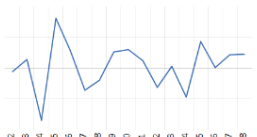

Luxembourg

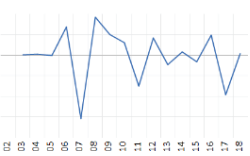

sweden

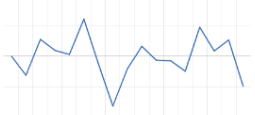

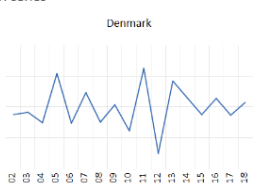

Greece

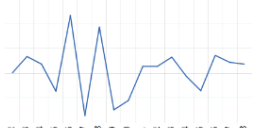

Netherlands

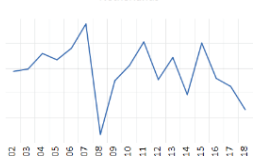

United Kingdom

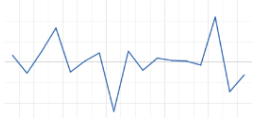

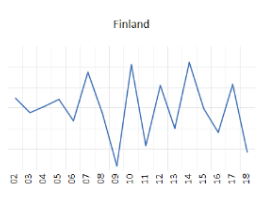

Ireland

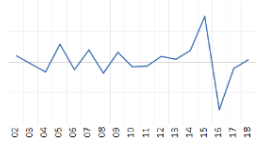

Portugal

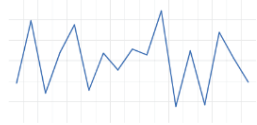

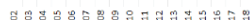


V. Bilas: What is the Relationship Between FDI and Economic Growth? Evidence from EU15 Countries Zbornik Veleučilišta u Rijeci, Vol. 8 (2020), No. 1, pp. 253-281

\section{Graph 12. $\triangle$ FDIP time series}

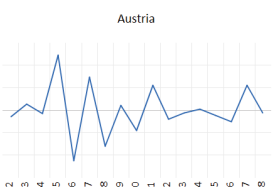

France

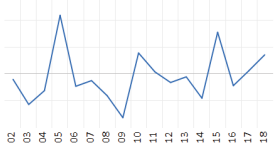

Italy

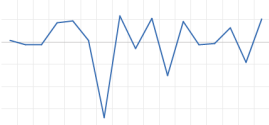

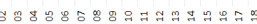
Spain

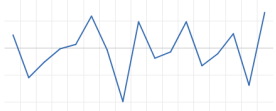

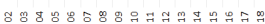

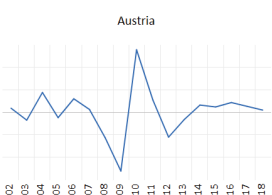

France

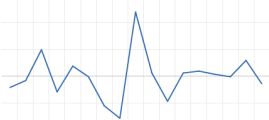

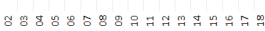

Italy

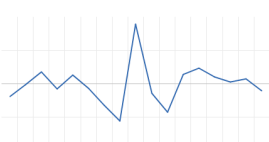

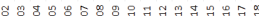

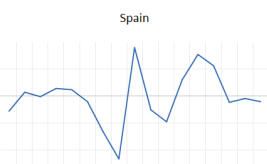

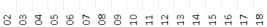

1st difference of FDP to GDP series

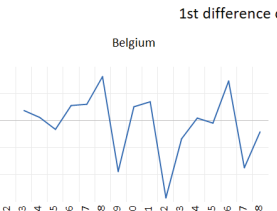

Germany

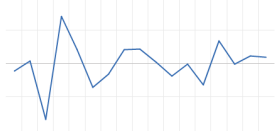

Luxembourg

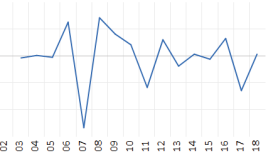

Sweden

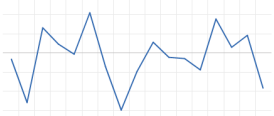

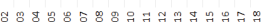

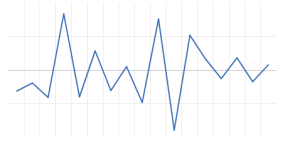

Greece

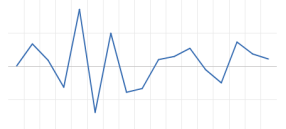

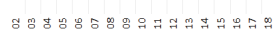

Netherlands

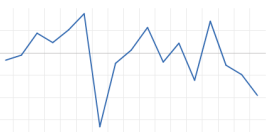

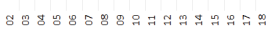
United Kingdom

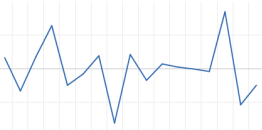

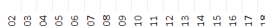

\section{Graph 13. $\triangle$ rGDP time series}
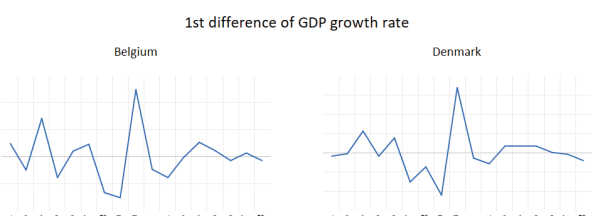

Greece

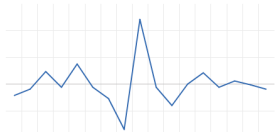

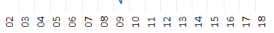

Luxembourg

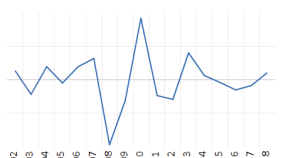

Sweden

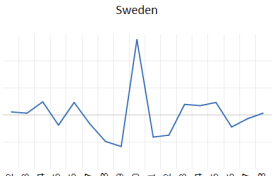

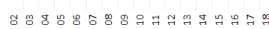

Netherlands

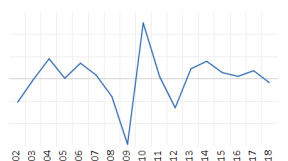

United Kingdom

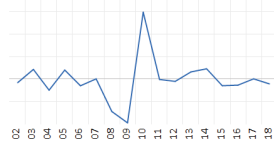

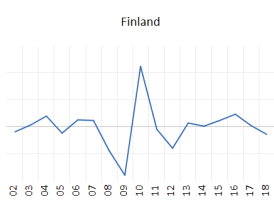

Ireland

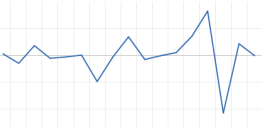

Portugal
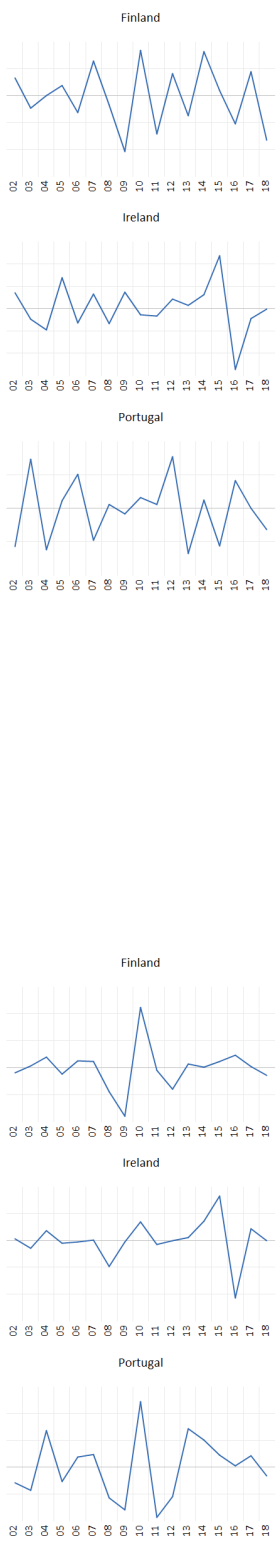

Ireland

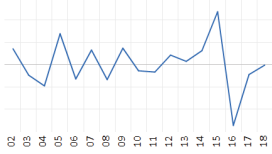

Portugal
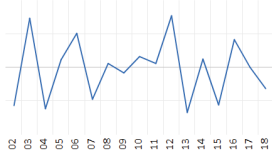

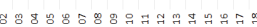


V. Bilas: What is the Relationship Between FDI and Economic Growth? Evidence from EU15 Countries Zbornik Veleučilišta u Rijeci, Vol. 8 (2020), No .1, pp. 253-281

\section{Graph 14. $\triangle \mathrm{rFDI}$ time series}

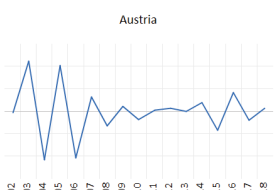

France

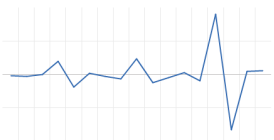

Italy

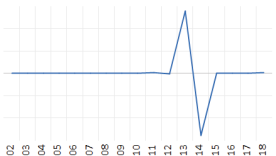

Spain

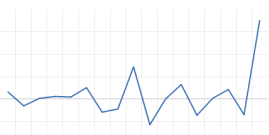

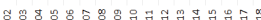

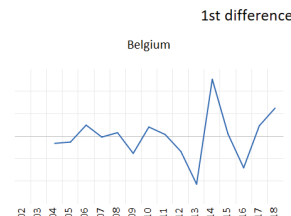

Germany

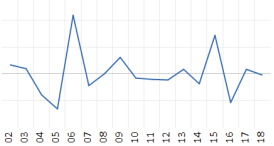

Luxembourg

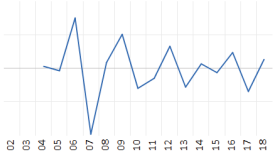

Sweden

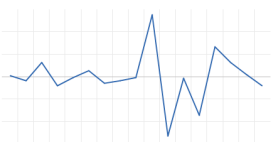

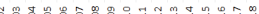

\section{Graph 15. $\triangle \mathrm{rFDIP}$ time series}

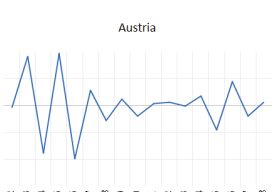

France

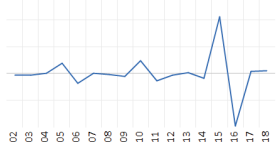

Italy

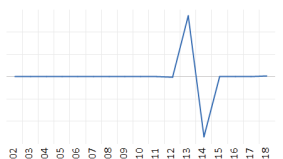

Spain

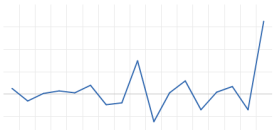

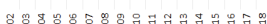

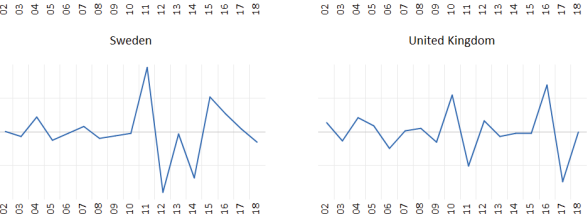

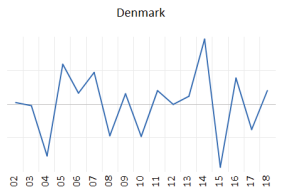

Greece

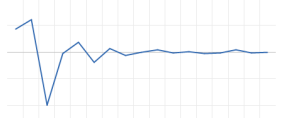

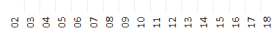

Netherlands

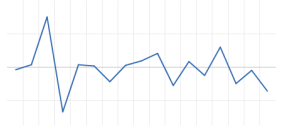

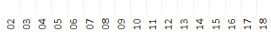
United Kingdom

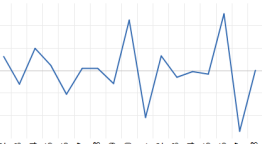

वृ

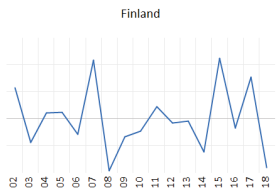

Ireland

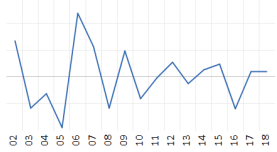

Portugal

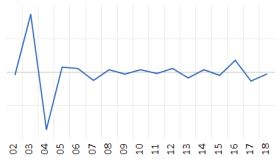

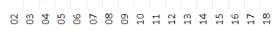

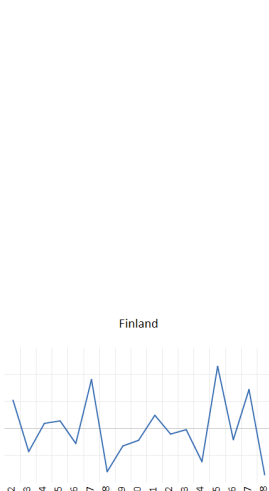

Ireland

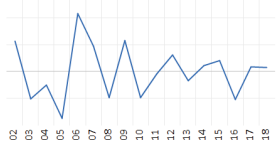

Portugal

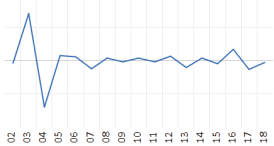


V. Bilas: What is the Relationship Between FDI and Economic Growth? Evidence from EU15 Countries Zbornik Veleučilišta u Rijeci, Vol. 8 (2020), No. 1, pp. 253-281

\section{Graph 16. $\Delta$ LogGDP time series}

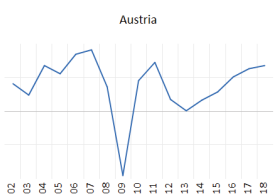

France

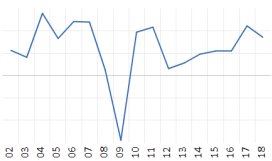

Italy

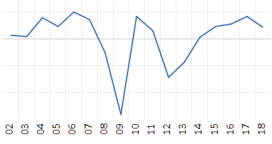

spain

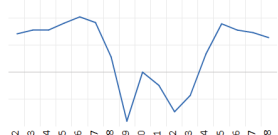

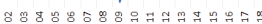

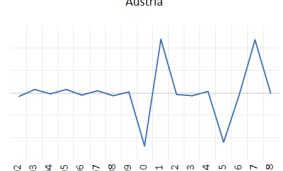

France

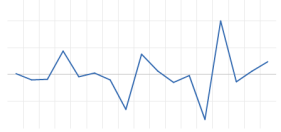

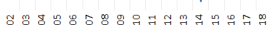

Italy

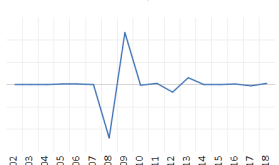

Spain

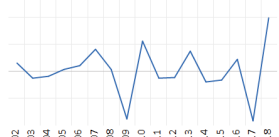

1st diff (Log of Real gross domestic product (constant 2011 international \$))

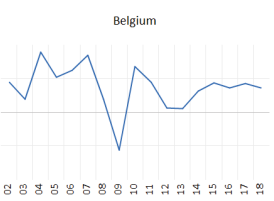

Germany

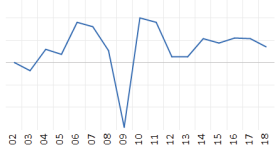

Luxembourg

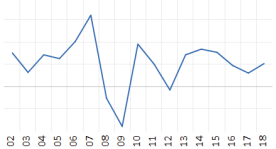

Sweden

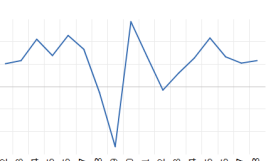

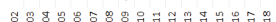

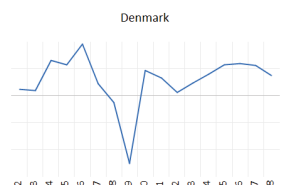

Greece

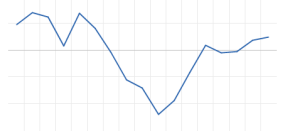

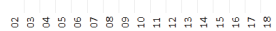

Netherlands

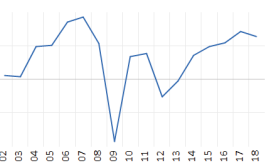

United Kingdom

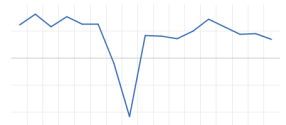

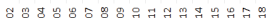

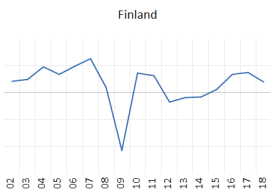

Ireland

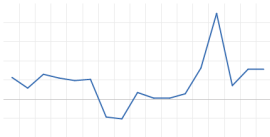

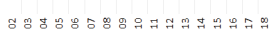

Portugal

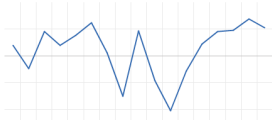

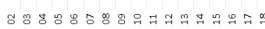

Graph 17. $\Delta$ LogFDI time series

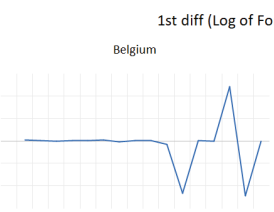

Germany

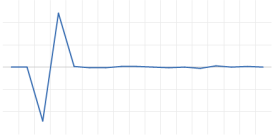

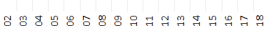

Luxembourg

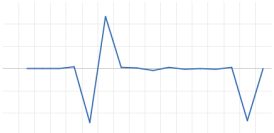

sweden

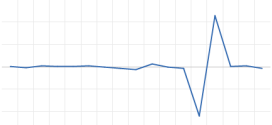

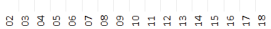

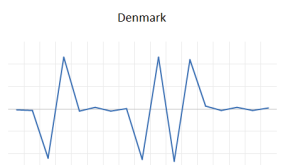

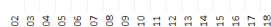
Greece

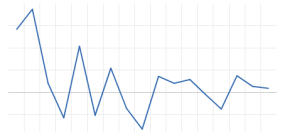

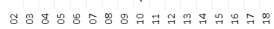

Netherlands

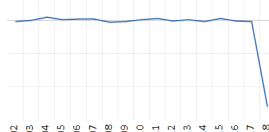

United Kingdom

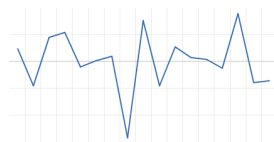

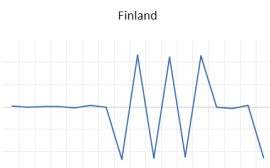

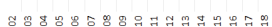
Ireland

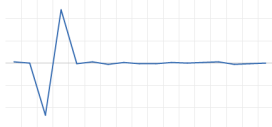

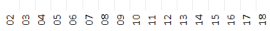

Portugal

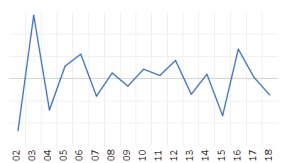


V. Bilas: What is the Relationship Between FDI and Economic Growth? Evidence from EU15 Countries Zbornik Veleučilišta u Rijeci, Vol. 8 (2020), No .1, pp. 253-281

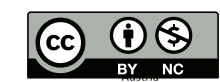

Creative Commons Attribution -

NonCommercial 4.0 International License

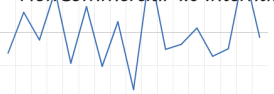

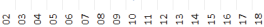

France

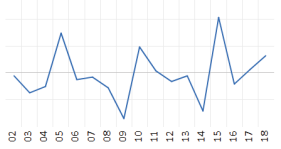

Italy

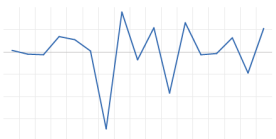

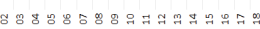

Spain

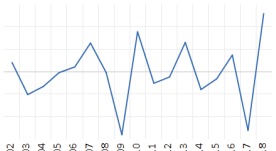

\section{Graph 18. $\Delta$ LogFDIP time series}

\section{1st diff (Log of Foreign direct investment to GDP)}

Belgium

Denmark

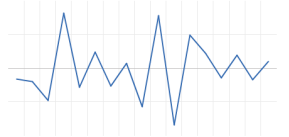

Greece

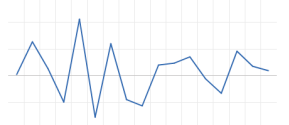

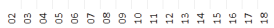

Netherlands

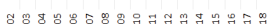

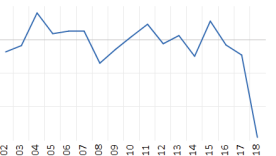

United Kingdom
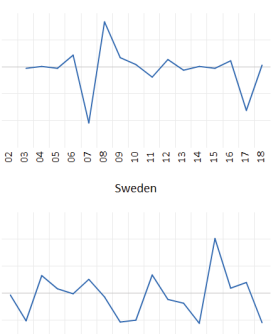

sweden

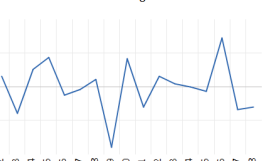

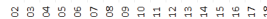

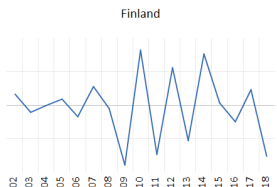

Ireland

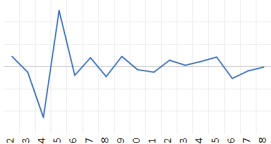

Portugal

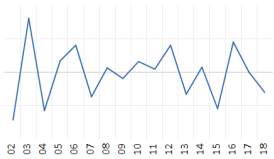




\title{
KOJA JE POVEZANOST IZMEĐU INOZEMNIH IZRAVNIH ULAGANJA I EKONOMSKOG RASTA? PRIMJER ZEMALJA EU15
}

\author{
Vlatka Bilas \\ Dr. sc., redovita profesorica, Sveučilište u Zagrebu, Ekonomski fakultet, \\ Katedra za međunarodnu ekonomiju, Trg J. F. Kenedyja 6, 10000 Zagreb, Hrvatska; \\ e-mail:bilas.vlatka@gmail.com
}

\section{SAŽETAK}

Cilj rada je istražiti povezanost inozemnih izravnih ulaganja (FDI) i ekonomskog rasta u zemljama EU15 tijekom razdoblja 2002-2018. EU15 čini skupina zemalja koje su ušle u Europsku uniju prije najvećeg proširenja 2004. godine, a posljednji put 1995. godine (Austrija, Belgija, Danska, Finska, Francuska, Njemačka, Grčka, Irska, Italija, Luksemburg, Nizozemska, Portugal, Španjolska, Švedska i Ujedinjeno Kraljevstvo). Zaključci iz rada doprinose postojećoj literaturi o utjecaju inozemnih izravnih ulaganja na ekonomski rast. U radu se koriste testovi jediničnih korijena, testovi panel kointegracije (ARDL model) i Grangerova uzročnost. Prema procijenjenom ARDL modelu postoji dugotrajna ravnoteža između LogGDP, LogFDI i LogFDIP (logaritam udjela FDI u BDP-u) serija. Stopa prilagođavanja vraćanja u ravnotežu je između 4,43\% i 5,95\%. Svi koeficijenti su pozitivni u dugom roku, ali nisu svi statistički značajni. U slučaju LogFDIP serije, koeficijenti su statistički značajni i variraju između 0,1226 i 0,4398. Ti koeficijenti pokazuju da porast LogFDIP od 1\% povećava LogGDP između 0,1226\% i 0,4398\% u dugom roku. Rezultati Dumitrescu-Hurlin testa uzročnosti pokazali su kako postoji samo jednosmjerna uzročna veza od stope rasta BDP-a i stope rasta FDI te stope rasta BDP-a prema LogFDIP. Zaključno, postoje slabi dokazi da su inozemna izravna ulaganja imala statistički značajan utjecaj na BDP u zemljama EU15.

Ključne riječi: testovi jediničnih korijena, testovi kointegracije, Grangerova uzročnost, EU15 